\title{
Discussion Paper No. 15-011 \\ Peeling the Onion: Analyzing Aggregate, National and Sectoral Energy Intensity in the European Union
}

Andreas Löschel, Frank Pothen, and Michael Schymura

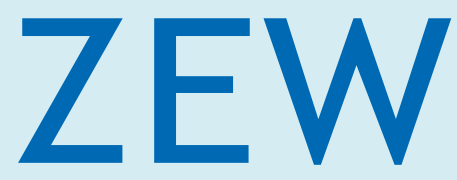

Zentrum für Europäische Wirtschaftsforschung $\mathrm{GmbH}$

Centre for European

Economic Research 


\title{
Discussion Paper No. 15-011 \\ Peeling the Onion: Analyzing Aggregate, National and Sectoral Energy Intensity in the European Union
}

\author{
Andreas Löschel, Frank Pothen, \\ and Michael Schymura
}

Download this ZEW Discussion Paper from our ftp server:

http://ftp.zew.de/pub/zew-docs/dp/dp15011.pdf

Die Discussion Papers dienen einer möglichst schnellen Verbreitung von neueren Forschungsarbeiten des ZEW. Die Beiträge liegen in alleiniger Verantwortung der Autoren und stellen nicht notwendigerweise die Meinung des ZEW dar.

Discussion Papers are intended to make results of ZEW research promptly available to other economists in order to encourage discussion and suggestions for revisions. The authors are solely responsible for the contents which do not necessarily represent the opinion of the ZEW. 


\title{
PEELING THE ONION:
}

\section{Analyzing Aggregate, National and Sectoral ENERGY INTENSITY IN THE EUROPEAN UNION}

\author{
ANDREAS LÖSCHEL, FRANK POTHEN ${ }^{\dagger}$ AND MICHAEL SCHYMURA ${ }^{\ddagger}$
}

\begin{abstract}
One of the most promising ways of meeting climate policy targets is improving energy efficiency, i.e. reducing the amount of scarce and polluting resources needed to produce a given quantity of output. This study undertakes an empirical exercise using the World Input-Output Database (WIOD), a harmonized dataset comprising time-series of input-output tables along with environmental satellite accounts and socioeconomic information. The paper consists of two parts. In the first part we begin with an aggregated picture of EU27 energy intensity and its evolution between 1995 and 2009 . Then we dig deeper and introduce sectoral detail to identify the economic changes that occurred during the same period. Finally, we disaggregate the EU27 into countries for regional analysis and perform a sectoral disaggregation for a fine-grained picture of energy intensity in Europe. In the second part of the study we take our findings from index decomposition analysis and subject them to panel estimations. The objective is to control for factors that may have shaped the evolution of energy intensity in the European Union. In particular, we investigate the impact of technological change, structural change, trade, environmental regulation and country-specific characteristics.
\end{abstract}

Keywords: Environmental and Climate Economics, Energy Intensity, Index Decomposition JEL-Classification: Q0, Q50

*University of Münster and Centre for European Economic Research (ZEW). Corresponding author: Am Stadtgraben 9, D-48143 Münster; Email: andreas.loeschel@wiwi.uni-muenster.de.

${ }^{\dagger}$ Centre for European Economic Research (ZEW).

${ }^{\ddagger}$ Centre for European Economic Research (ZEW).

Our research has benefited enormously from discussions with Marcel Timmer, Sascha Rexhäuser, Enrica de Cian, Elena Verdolini and Sebastian Voigt. We thank the European Commission for funding (Grant-No.: 225 281). We also thank the Bundesministerium für Bildung und Forschung (BMBF) for financial support (grant 01LA1105C). The usual disclaimer applies. 


\section{INTRODUCTION}

MPROVING ENERGY EFFICIENCY is one of the most promising ways of meeting the emission 1 targets set by climate policy. What is more, it may also help reduce dependence on fossil fuels and foster industrial competitiveness (Ang et al., 2010). This paper seeks to understand the decline of energy intensity (i.e. the reciprocal to energy efficiency) by using index decomposition analysis and econometric methods. We differentiate between structural changes (within-country structural effect), the effects of efficiency improvements (technology effect) and their regional and sectoral patterns (between-country structural effect).

We focus our analysis on Europe for a variety of reasons. First, the European Union regards itself as a leading actor in international climate policy and improving energy efficiency is a central pillar of its strategy 11 Second, the data we use allows us to consider an interesting period in Europe. Our sample starts shortly after the fall of the Iron Curtain and includes periods with climate policy and without. Finally, and most importantly, the European integration process is an outstanding example of structural change at work. Other studies have focused on the impact of NAFTA's impact on pollution (Grossman and Krueger, 1991) or on countries in which structural changes have occurred. But no case examined so far involves large charges to the openness of cross-country trade (as e.g. Antweiler et al. (2001); Cole (2006); Cole and Elliott (2003) and Managi et al. (2009)).

Previous studies of energy intensity have either a different regional focus, a limited time period, or are rather descriptive. ${ }^{2}$ A number of available contributions focused on specific countries, most notably the US (among others Sue Wing, 2008; Metcalf, 2008; Huntington, 2010), and more recently also emerging economies such as China (Zhang, 2003, Fisher-Vanden et al., 2004 Ma and Stern, 2008; Wu, 2012), India, and South Korea (Sanstad et al., 2006). When an international dimension is present, the study is usually limited to industrialized economies (e.g. Mulder and De Groot, 2012). Alcantara and Duarte (2004), for example, use structural decomposition analysis to investigate the energy intensities in 14 European countries and 15 sectors, though the authors restrict their analysis to 1995. Cornillie and Fankhauser (2004) investigate the development of energy intensity for transitional economies, but their time frame is brief (six years) and spans the years in which structural break took place: 1992 to 1998 . The study by Voigt et al. (2014) investigates energy intensity development in 40 major economies (including developing countries such as China, Brazil and Russia) but it is rather descriptive since it only relies on the index decomposition methodology.

The time-series character, the regional resolution of our data, and the construction of important variables in combination with econometric estimations allows us to investigate evolved changes of the energy intensity in the European Union.

We employ the World Input-Output Database (WIOD) to tell a story about the evolution of energy intensity in Europe between 1995 and 2009. As the graphs below show, the gross aggregate output of the EU 27 increased by $37.2 \%$ (Figure $1 \mathrm{a}$ and total energy use decreased

\footnotetext{
${ }^{1}$ In its cost-benefit analysis of the new European Energy Efficiency Directive, the European Commission concludes optimistically that the annual cost of 24 billion euros estimated for the period of 2011 to 2020 will be outweighed by the annual benefits, projected at 44 billion euros (European Commission 2012).

${ }^{2}$ For further information on energy efficiency we recommend the reader to look at the comprehensive survey by Linares and Labandeira (2010).
} 
by $0.4 \%$ (Figure $1 \mathrm{~b}$ ) in this period. As a result of both, energy intensity declined steadily by $27.4 \%$ (Figure 1c). Note that the gross output declined by $5.9 \%$ and energy use by $6.2 \%$ between 2008 and 2009 due to the financial crises. The energy intensity did not experience a visible shock between those years.

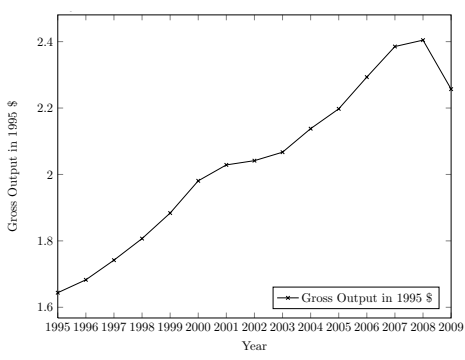

(a) Gross Output

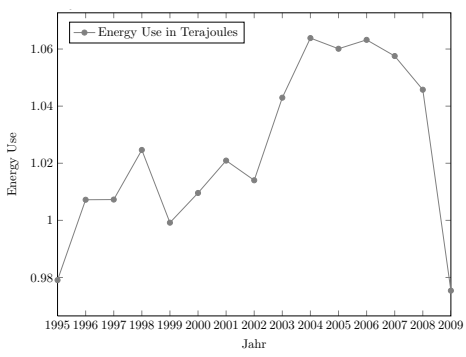

(b) Energy Use

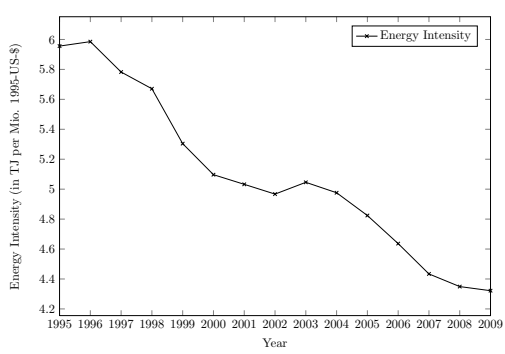

(c) Resulting Energy Intensity

Figure 1: Gross Output, Energy Use and Energy Intensity in the EU27 1995-2009

These three figures appear to tell us everything, and yet they reveal nothing. Is the decline in energy intensity due to a shift in the composition of the European economy as a whole as it moves away from energy-intensive production towards less energy-intensive production? Or are more fundamental improvements to energy utilization responsible for the decline? And how did individual countries perform during the same time? What are the main economic and political drivers?

The questions posed above have fundamental importance: if the decline in energy intensity could be obtained simply by structural improvements and increasing imports of energy-intensive goods from outside Europe, the pattern in Europe would not be replicable in other, less developed regions ${ }^{3}$ But if the decrease in energy intensity is due to increased efficiency, the trajectory would be replicable in other regions of the world. Thanks to technology transfers, spillover effects, economies of scale, and learning-by-doing, achieving the same trajectory elsewhere might even be easier. As Wolfram et al. (2012) argue, energy consumption in OECD and non-OECD countries was almost equal in 2007, "[...] but from 2007 to 2035, it [the U.S. Energy Information Administration] forecasts that energy consumption in OECD countries will grow by 14 percent, while energy consumption in non-OECD countries will grow by 84 percent" (Wolfram et al., 2012 , p. 119). Given this information, the investigation of the replicability of the European decline assumes tremendous importance. Indeed, a key finding of this paper is that a substantial share of the decrease of energy intensity can be attributed to various facets of technological change. In other words: energy intensity is replicable in less developed countries.

Our study consists of two interrelated parts and is organized as follows. In the first part we describe the different data sources we employ. Next we perform an index decomposition analysis of the energy intensity in Europe between 1995 and 2009. We show measures from a two-factor index decomposition for the individual countries. Next, we apply a three-factor decomposition for the EU 27 aggregate to separate two different structural effects: within-country and betweencountry structural change. Our analysis reveals a large heterogeneity within Europe. While some countries experienced a decline in energy intensity due to structural change, most countries

\footnotetext{
${ }^{3}$ For a similar argument applied to the impact of international trade on pollution in U.S. manufacturing between 1987 and 2001, see Levinson (2009).
} 
benefited from technology improvements. We then construct variables for the potential drivers behind the different effects, including estimates for total factor productivity, trade openness, income per capita, environmental regulation, energy prices, and country characteristics. Subsequently, we present the results of our empirical exercise and discuss their implications. Finally we draw some conclusions in section $\mathrm{V}$.

\section{DATA}

\section{A. THE WIOD}

Our analysis relies on data from the World Input-Output Database (WIOD) 4 It provides a comprehensive, harmonized dataset that permits comparison of specific environmental indicators like energy intensity over the years covered by the database (1995 to 2009). The WIOD is based on national accounts data harmonized for international comparability. The dataset covers 40 countries (27 EU countries and 13 other major countries), which together account for $\approx$ $80-85 \%$ of the world's GDP in 2009. The data is disaggregated into 34 industries (agriculture, manufacturing, and services). Besides the broad country coverage, the sectoral disaggregation and the time range, the dataset has another key advantage: it contains several unified satellite accounts with the same sectoral classification as the core dataset. The satellite accounts consist of bilateral trade data, socioeconomic data (different skill types of labor, sectoral and total capital stocks, etc.) and, most important for this analysis, a rich set of environmental information. The environmental satellites cover the following data: energy use broke down by several energy carriers (fossil, non-fossil, renewables, etc.), emissions of greenhouse gases $\left(\mathrm{CO}_{2}, \mathrm{~N}_{2} \mathrm{O}, \mathrm{CH}_{4}\right)$, air pollutants relevant for acidification $\left(\mathrm{SO}_{2}, \mathrm{NO}_{\mathrm{X}}, \mathrm{CH}_{4}\right)$ and tropospheric ozone information $\left(\mathrm{NO}_{\mathrm{X}}, \mathrm{NMVOC}, \mathrm{CH}_{4}\right)$.

To perform the index decomposition analysis and the empirical study in the second part of the paper, we have used the following information from the WIOD for all 27 current European Union countries: the Socioeconomic Accounts Files $(S E A)$ and the Energy Use Files (Gross $(E U))$.

We use annual sectoral output $(G O)$ in year $t$ as our measure of economic activity. It is expressed in monetary units in basic prices of 1995 and converted to mio. US-\$ (1995) using the supplied exchange rates.5.$^{5}$ One advantage of the WIOD is the availability of sectoral price deflators, so that different price developments can be taken into account, not only on a national level but also on a sectoral one. We use hours worked by employees as a measure of labor input $\left(H_{-} E M P E\right)$. Data on three types of labor quality is also included (low-skilled $\left(L A B_{-} L S\right)$, medium-skilled $\left(L A B_{-} M S\right)$ and high-skilled $\left(L A B_{-} H S\right)$. Another advantage of the WIOD is the capital stock variable. It is generally hard to obtain (physical) capital stock data from official

\footnotetext{
${ }^{4}$ The WIOD and all satellite accounts are available at http://www.wiod.org For this paper, we have used data from February 2012.

${ }^{5}$ An alternative measure of economic activity is value added. It is indeed a better measure for labor productivity. However, gross output might be preferable when dealing with multi-factor productivity and it better captures disembodied technological change. Moreover, the value added for some sectors in Denmark, Slovakia and Poland turned out to be negative and hence it was not suitable for the index decomposition approach. The results using value added instead of gross output did not change tremendously and they are available from the authors.
} 
data sources. The WIOD offers information about physical capital stocks and gross fixed capital formation for each country, sector and year $\left(K_{-} G F C F\right.$ and $\left.G F C F\right)$. We used this information to construct capital-to-labor ratios $(K L)$ and to take capital vintaging into account (VINTAGING). We have also used information on bilateral trade flows to capture the effect of structural change (OPENESS).

Energy is measured in physical units (TJ) and is aggregated across 26 energy carriers $(E U)$. The sectoral classification of energy use is exactly congruent to the WIOD's socioeconomic data.

\section{B. Other DATA}

The other data sources are the Penn World Tables (Mark 7.0, Heston et al., 2011), the CIA World Fact Book 6 , the CEPII Gravity Data Set (Meyer, 2011) 7 information on energy efficiency regulation from the International Energy Agency the Barro and Lee database on educational attainment (Barro and Lee, 2010), Eurostat for energy prices and climate variables ${ }^{9}$ and Psacharopoulos and Patrinos (2004) for estimated social Mincearian returns on education. A complete list of the regions and sectors covered by this analysis is given in Appendix A and the summary statistics in Appendix B.

We use the Penn World Tables (Mark 7.0) to obtain information about real GDP per capita (variable $r g d p c h$ ), population ( $p o p$ ), real openness as defined by the sum of imports and exports divided through GDP (openk) and real investment as a fraction of GDP (ki) (Heston et al., 2011). The information about the geographical country characteristics, such as area, was obtained from the CIA World Fact Book and the CEPII Gravity Data Set. Information on environmental regulation was collected from the International Energy Agency; from it we constructed an index for the extent and stringency of environmental regulation. 10 In addition, we used the Barro and Lee database (Barro and Lee, 2010) on educational attainment and Psacharopoulos and Patrinos (2004) for estimated social Mincearian returns on education to construct our measure for human capital. Energy prices (PRICE) and heating degree days (HDD) were collected from Eurostat.

\section{The Mean Divisia Index Decomposition of ENERgY INTENSITY}

The development of energy intensity in the economy can be attributed to two different but equally relevant changes. On the one hand, energy intensity can increase or decline as a result of changes in the industrial activity composition (structural effect). On the other hand, overall energy intensity changes may also result from sectoral energy efficiency improvements or deteriorations (technology effect). Two broad categories of decomposition methodologies can be applied to disentangle these effects: approaches based on input-output analysis, called structural

\footnotetext{
6 https://www.cia.gov/library/publications/the-world-factbook/

7 http://www.cepii.fr/CEPII/en/bdd_modele/presentation.asp?id=8

8 http://www.iea.org/textbase/pm/index.htm IEA (2012)

9 http://epp.eurostat.ec.europa.eu/portal/page/portal/eurostat/home/

${ }^{10}$ We thank Enrica de Cian, Elena Verdolini and Sebastian Voigt for providing us with their data on environmental regulation.
} 
decomposition analysis (SDA), and disaggregation techniques which can be referred to as index decomposition analysis (IDA) and which are related to index number theory in economics 11

We use an index decomposition approach (IDA) as described by Ang and Choi (1997); Ang and Liu (2007); Boyd et al. (1987); Ang et al. (2010) and more recently by Choi and Ang (2012) or Su and Ang (2012) for total, sectoral and national energy intensities. We focus on the structural changes that affect the supply side of the economy (productive sectors) and thus exclude the private households.

Following Ang and Choi (1997), we rely on multiplicative decomposition and use the "logarithmic mean Divisia index" (LMDI-II) approach Ang, 2004).12

This methodology offers very important advantages: (1) it is zero-value robust (Ang et al. 1998, p. 491) and (2) it "yields perfect decomposition" (Ang et al., 1998, p. 495), i.e. no unexplained residual exists. The latter is a considerable advantage compared to the arithmetic mean Divisia index where the residual can be different from zero "when changes in the variables [...] are substantial", as in the case where the methodology is used in cross-country analyses Ang and Choi, 1997, p. 1165) ${ }^{13}$

\section{A. Country-Level IDA}

Our variable of interest is total energy intensity of economy $j$ at time $t$. It is defined for each country as a weighted average of sectoral energy intensities,

$$
I_{j, t}=\sum_{i} \frac{G O_{i, j, t}}{G O_{j, t}} \frac{E U_{i, j, t}}{G O_{i, j, t}}=\sum_{i} S_{i, j, t} I_{i, j, t}
$$

with the following notation:

- period: $t \in\{1995,2009\}$,

- sectors: $i=1, \ldots, 34$,

- countries: $j=1, \ldots, 27$,

- sectoral energy use of sector $i$ in country $j$ and period $t: E U_{i, j, t}$,

\footnotetext{
${ }^{11}$ See Diewert (1993) for a technical summary of index number theory. Boyd et al. (1987) offer a more comprehensive review of different indices in the context of energy intensity and the index number problem in economics. The SDA and IDA are not the only approaches for analyzing energy intensity trends. Kim and Kim (2012), for instance, employ Data Envelopment Analysis (DEA) to compare international energy intensity trends. The DEA approach allows to find the countries lying on a technological frontier and to calculate the distances of other countries to this frontier. Ma and Stern (2008) summarize the main advantages and disadvantages of each approach.

${ }^{12}$ The difference between LMDI-I and LMDI-II can be found, beside a slightly different weight function, in the residual terms at the sub-category level. It means that, although LMDI-II provides decomposition results which are not perfect at the sub-category level, the sum of the residual terms for all the sub-categories is always zero so that LMDI-II still gives results which are perfect in decomposition. Similarly to the Office of Energy Efficiency and Renewable Energy of the United States we have decided to use the multiplicative LMDI-II approach.

${ }^{13}$ An alternative approach is additive decomposition. In addition, one could choose between alternative indicators, such as Paasche or Laspeyres indices. However, due to unexplained residuals during the decomposition procedure which also arise for those types of indices, we prefer the logarithmic mean Divisia index.
} 
- energy use of country $j$ in period $t: E U_{j, t}=\sum_{i} E U_{i, j, t}$,

- sectoral gross output of sector $i$ in country $j$ and period $t: G O_{i, j, t}$,

- gross output as a measure of economic activity of country $j$ in period $t: G O_{j, t}=\sum_{i} G O_{i, j, t}$,

- share of sector $i$ in total gross output of country $j$ in period $t: S_{i, j, t}=\frac{G O_{i, j, t}}{G O_{j, t}}$,

- sectoral energy intensity of sector $i$ in country $j$ and period $t: I_{i, j, t}=\frac{E U_{i, j, t}}{G O_{i, j, t}}$, and

- total energy intensity of country $j$ in period $t: I_{j, t}=\frac{E U_{j, t}}{G O_{j, t}}$.

The multiplicative decomposition of change in total energy intensity between the periods $t$ and $t+1$ is then described by

$$
D_{T o t, j, t+1}=\frac{I_{j, t+1}}{I_{j, t}}=D_{S t r, j, t+1} D_{I n t, j, t+1} .
$$

$D_{S t r, j, t+1}$ is the estimated impact of structural change on total energy intensity in period $t+1$. $D_{\text {Int }, j, t+1}$ is the estimated impact of changes in the sectoral energy intensity levels in period $t+1$ which can be explained by a change in the efficiency of the corresponding sector (technology effect). The formulae for the log mean Divisia index decomposition are

$$
\begin{aligned}
& D_{S t r, j, t+1}=\exp \sum_{i} \frac{L\left(\omega_{i, j, t+1}, \omega_{i, j, t}\right)}{\sum_{i} L\left(\omega_{i, j, t+1}, \omega_{i, j, t}\right)} \ln \left(\frac{S_{i, j, t+1}}{S_{i, j, t}}\right), \\
& D_{\text {Int }, j, t+1}=\exp \sum_{i} \frac{L\left(\omega_{i, j, t+1}, \omega_{i, j, t}\right)}{\sum_{i} L\left(\omega_{i, j, t+1}, \omega_{i, j, t}\right)} \ln \left(\frac{I_{i, j, t+1}}{I_{i, j, t}}\right),
\end{aligned}
$$

where

$$
L\left(\omega_{i, j, t+1}, \omega_{i, j, t}\right)=\frac{\omega_{i, j, t+1}-\omega_{i, j, t}}{\ln \left(\frac{\omega_{i, j, t}}{\omega_{i, j, t+1}}\right)}
$$

is the logarithmic mean of $\omega_{i, j, t+1}$ and $\omega_{i, j, t} . \omega_{i, j, t}$ is the sectoral share of energy consumption within a given country, $\omega_{i, j, t}=\frac{E U_{i, j, t}}{E U_{j, t}}$. As proposed by Ang et al. (2010), we use chaining decomposition, i.e. the specific annual values are computed on a rolling basis (from 1995 to 1996, from 1996 to 1997 etc.) where the value for 1995 is set equal to 1 . These results are "chained" to obtain a time series from 1995 to 2009 (Ang et al. 2010, p. 1428).14

\section{B. EU 27 IDA}

The approach outlined in the previous subsection can be extended in order to conduct an index decomposition analysis at the aggregate European level. Therefore, we define European (aggregate) total energy intensity at time $t$,

$$
I_{t}=\sum_{j} \sum_{i} \frac{G O_{j, t}}{G O_{t}} \frac{G O_{i, j, t}}{G O_{j, t}} \frac{E U_{i, j, t}}{G O_{i, j, t}}=\sum_{j} \sum_{i} S_{j, t} S_{i, j, t} I_{i, j, t},
$$

\footnotetext{
${ }^{14}$ For a theoretical consideration of chaining decomposition see also Ang 1994 pp. 169ff.).
} 
with the additional notation:

- EU27's energy use in period $t: E U_{t}=\sum_{j} E U_{j, t}$,

- total EU27's gross output in period $t: G O_{t}=\sum_{j} G O_{j, t}$,

- share of country $j$ in total EU27's gross output in period $t: S_{j, t}=\frac{G O_{j, t}}{G O_{t}}$, and

- total EU27's energy intensity in period $t: I_{t}=\frac{E U_{t}}{G O_{t}}$.

This enables us to perform a three factor decomposition at the European level analogous to equation III.2,

$$
D_{T o t, t+1}=\frac{I_{t+1}}{I_{t}}=D_{b S t r, t+1} D_{w S t r, t+1} D_{I n t, t+1} .
$$

In this case, we distinguish two aspects of structural change, a between-country structural effect, $D_{b S t r, t+1}$, and a within-country structural effect, $D_{w S t r, t+1}$. An increase of the former effect corresponds to a shift of the European economy toward more energy-intensive countries. On the other hand, an increase in the latter effect denotes a shift toward more energy-intensive sectors within the EU. The European technology effect, $D_{\text {Int }, t+1}$, describes the overall energy efficiency change aggregated over each sector and each country. The corresponding formulae for the log mean Divisia index decomposition are

$$
\begin{aligned}
D_{b S t r, t+1} & =\exp \sum_{j} \sum_{i} \frac{L\left(\tilde{\omega}_{i, j, t+1}, \tilde{\omega}_{i, j, t}\right)}{\sum_{j} \sum_{i} L\left(\tilde{\omega}_{i, j, t+1}, \tilde{\omega}_{i, j, t}\right)} \ln \left(\frac{S_{j, t+1}}{S_{j, t}}\right), \\
D_{w S t r, t+1} & =\exp \sum_{j} \sum_{i} \frac{L\left(\tilde{\omega}_{i, j, t+1}, \tilde{\omega}_{i, j, t}\right)}{\sum_{j} \sum_{i} L\left(\tilde{\omega}_{i, j, t+1}, \tilde{\omega}_{i, j, t}\right)} \ln \left(\frac{S_{i, j, t+1}}{S_{i, j, t}}\right), \\
D_{I n t, t+1} & =\exp \sum_{j} \sum_{i} \frac{L\left(\tilde{\omega}_{i, j, t+1}, \tilde{\omega}_{i, j, t}\right)}{\sum_{j} \sum_{i} L\left(\tilde{\omega}_{i, j, t+1}, \tilde{\omega}_{i, j, t}\right)} \ln \left(\frac{I_{i, j, t+1}}{I_{i, j, t}}\right) .
\end{aligned}
$$

The logarithmic mean $L\left(\tilde{\omega}_{i, j, t+1}, \tilde{\omega}_{i, j, t}\right)$ is defined analogously to equation III.5, but $\omega_{i, j, t}$ has to replaced by the more fine-grained parameter $\tilde{\omega}_{i, j, t}$ describing the share of energy use of each country and sector within European energy use, $\tilde{\omega}_{i, j, t}=\frac{E U_{i, j, t}}{E U_{t}}$. Also in this case we apply chaining decomposition.

\section{DeComposing EnERgy INTENSITY ON A COUNTRY-LEVEL}

In this section, we perform the index decomposition on the individual European countries. Figure 2 presents the annual growth rates of gross output and energy use (both in \%) between 1995 and 2009. The dotted lines represent the respective EU27 averages. Eastern European countries performed best (located in the lower right corner, implying above-average rises in gross output and below-average rises in energy use), while some of Europe most mature countries performed worst (located in the upper left corner, implying above-average rises in energy use and below-average rises in gross output).

We use Figure 2 to identify four country groups. Our summary of the results will be brief - most graphs tell their own tale - but we will take a moment to address some country-specific 


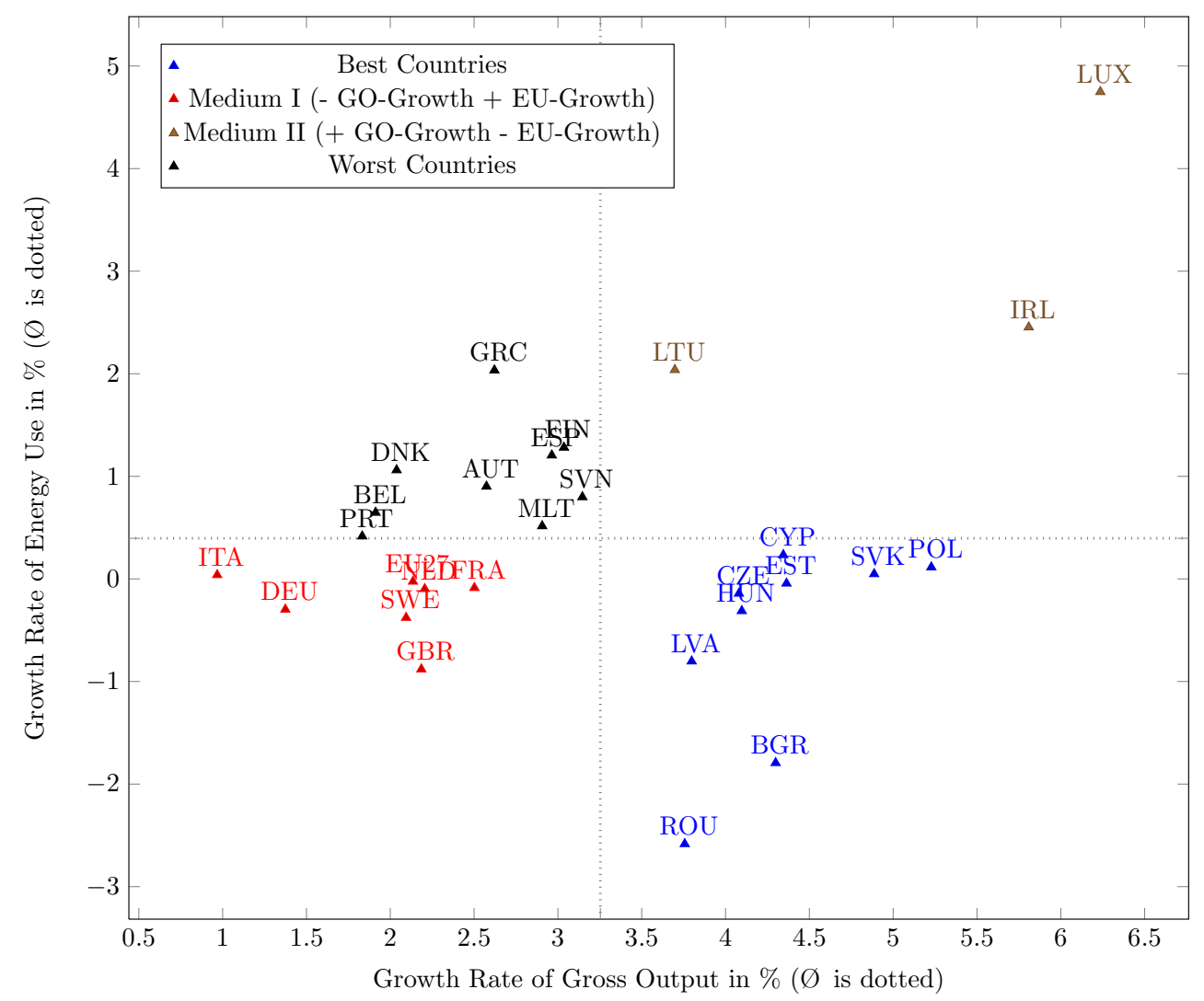

Figure 2: GO- and EU-Growth

peculiarities and refer the reader to the work of authors who delved into more detail. Our regional classification based on output and energy use growth for the 27 European countries is as follows:

- Best Countries (Above $\varnothing$ Output Growth, below $\varnothing$ Energy Use Growth): Bulgaria, Cyprus, Czech Republic, Estonia, Hungary, Latvia, Poland, Romania, Slovakia

- Medium I (Below Ø Output Growth, below Ø Energy Use Growth): France, Germany, Italy, Netherlands, Sweden, United Kingdom

- Medium II (Above Ø Output Growth, above Ø Energy Use Growth): Ireland, Lithuania, Luxembourg

- Worst Countries (Below Ø Output Growth, above Ø Energy Use Growth): Austria, Belgium, Denmark, Finland, Greece, Malta, Portugal, Slovenia, Spain

\section{Best Countries}

The 'best performing' group consists of Bulgaria, Cyprus, the Czech Republic, Estonia, Hungary, Latvia, Poland, Romania and Slovakia. All countries are characterized by an above-average rise in gross output and a below-average rise in energy use between 1995 and 2009.

Astonishingly, all countries save Cyprus are Eastern European. What is interesting about these countries is that they experienced the largest structural change in our sample. Cornillie and Fankhauser (2004) identified a decoupling of energy use and economic activity in the Baltic 
States (Estonia, Latvia and Lithuania) between 1992 and 1998. We can confirm this trend for Latvia and Estonia, though not for Lithuania, which is part of the Medium II country group (above-average rises in gross output, above-average rises in Energy Use). But while Latvia's improved energy intensity owed itself to better technology, the improvement in Estonia was driven by less energy-intensive production. Our results are in line with Balezentisa et al. (2011), who offer a detailed discussion of the policy measures that affected the development in Lithuania, notably the investments in modernizing buildings. Another example of improvement is Poland. As Gurgul and Lach (2012) note, in the past decade Poland's economic growth has been tied to changes in electricity utilization and to new, more energy-efficient technologies in the face of international environmental policy requirements. Romania and Bulgaria also experienced dramatically improved energy efficiency. As Popovici (2011) observed, "[t]he Romanian economy was in 1990 one of the most energy-intensive in the region - only Bulgaria's economy was more energy-intensive - due to the obsolete technologies [...] that were energy-intensive and had to import an increasing part of their raw materials. Due to the closure, technology upgrading and restructuring in the heavy industries, Romania is nowadays much less energy intensive" (Popovici, 2011, p. 1845). These economies experienced the largest structural change as also shown by other recent studies (Mulder and De Groot, 2012).

\section{Medium I}

The second country group is characterized by above-average growth in gross output and an above-average growth in energy use. It consists of France, Germany, Italy, Netherlands, Sweden and the United Kingdom, all mature European economies.

France and the Netherlands show a continuous decline in overall energy intensity, but while the economy in France shifted towards a more energy-intensive production, the economic composition in the Netherlands remained almost unaltered. The German economy moved towards more energy-intensive production, resulting in a $7 \%$ increase in the structural change index. Yet this effect is dominated by industrial improvement, as the nearly $30 \%$ decline in the technology index shows. The United Kingdom and Sweden are examples for countries, where both effects are decreasing, resulting in an overall energy intensity improvement of almost $40 \%$.

The moderate energy intensity reductions in these countries is likely due to their mature status as economies.

\section{Medium II}

The third country group is characterized by below-average growth in gross output and belowaverage growth in energy use. It consists of three small counties: Ireland, Lithuania and Luxembourg. Lithuania is the only Eastern European country, besides Slovenia, that is not located in the best performing country group.

\section{Worst Countries}

Our final group consists of countries that performed below the European average in both categories: Austria, Belgium, Denmark, Finland, Greece, Malta, Portugal, Slovenia and Spain. Mendiluce et al. (2010) compared the evolution of energy intensity in Spain with 15 other European countries (including Portugal and Greece). Our analysis confirmed their finding that Spain's energy intensity reached its highest level in 2004. Thereafter it declined, mainly due to the sharp decrease in the technology effect. We also confirmed the findings of Mendiluce et al. 


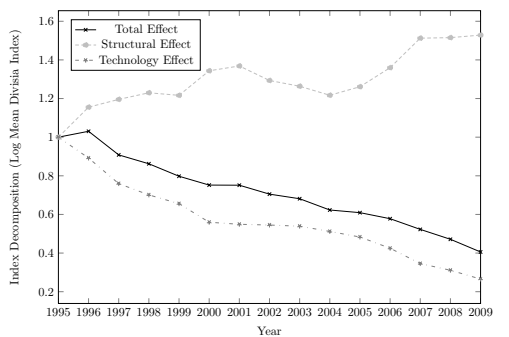

(a) Bulgaria

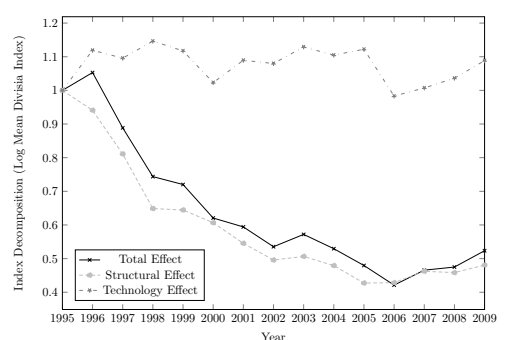

(d) Estonia

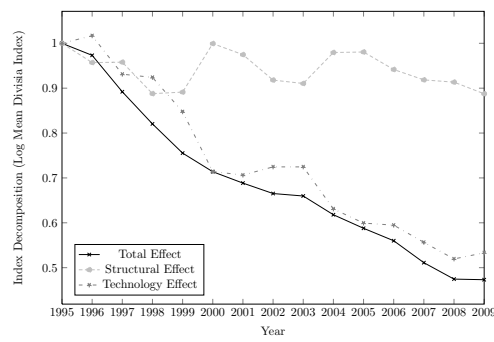

(g) Poland

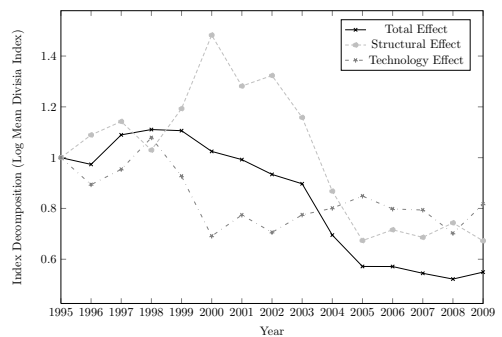

(b) Cyprus

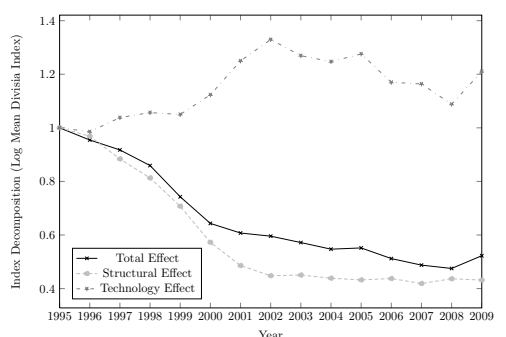

(e) Hungary

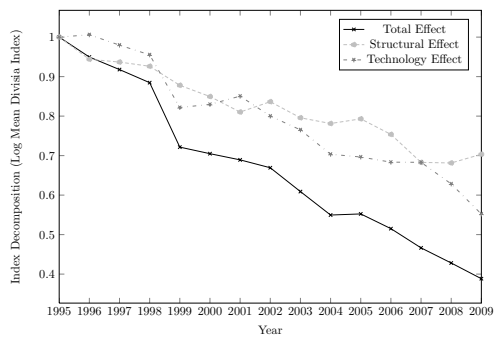

(h) Romania

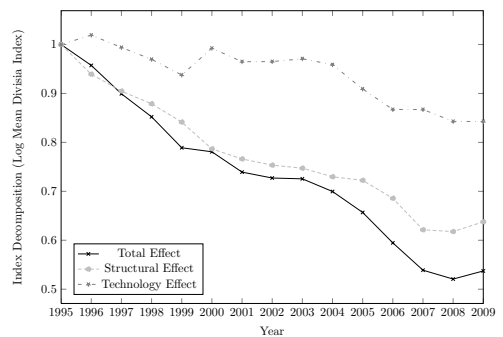

(c) Czech Republic

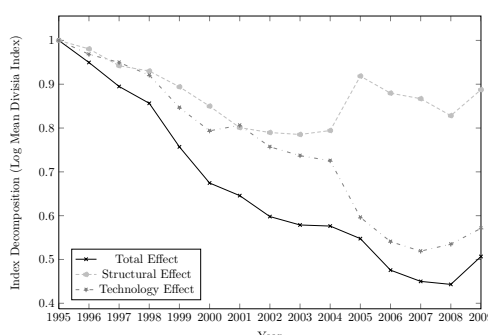

(f) Latvia

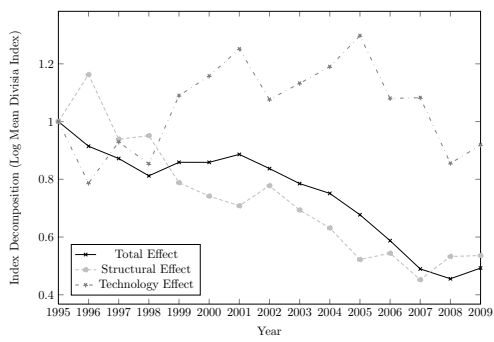

(i) Slovakia

Figure 3: IDA for the best performing countries

(2010) for other southern European countries: energy intensity remained almost unaltered, with the exception of Cyprus, which is located in our 'best performing' country group.

\section{The EU27-AgGREgATE: Three-FACTOR DECOMPOSITION}

In this subsection we present the results of the three-factor decomposition at the European level. Figure 7 highlights the contribution of the technology and the two structural effects (within-country and between-country) on aggregate energy intensity changes. We compute these effects according to equations III.6 to III.10.

Figure 7 suggests that the overall decline in aggregate energy intensity observed between 1995 and 2009 is the result of technological change and within-country structural change in the European economy. That is, improved technology and a shift towards less energy-intensive industries drove energy intensity down.

We observe three phases with respect to total energy intensity decline. In the first phase, between 1995 and 2000, the decrease in aggregate energy intensity is basically due to a shift toward less energy-intensive sectors and less due to improvements in energy intensities. In the second phase, between 2000 and 2003, aggregated energy intensity remains almost unaltered. 


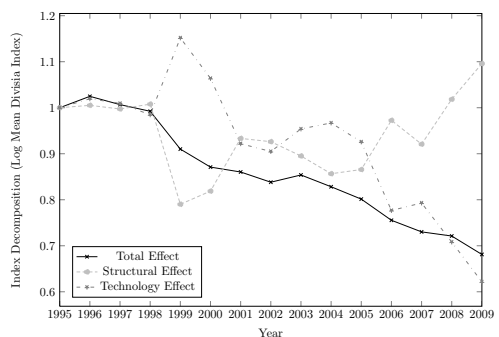

(a) France

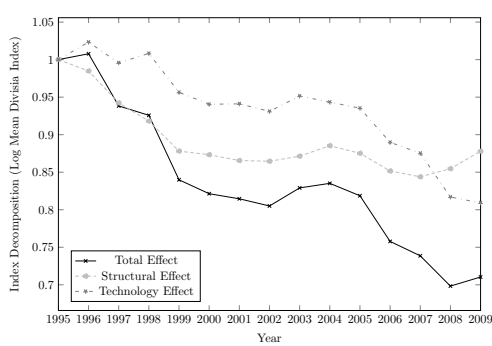

(d) Netherlands

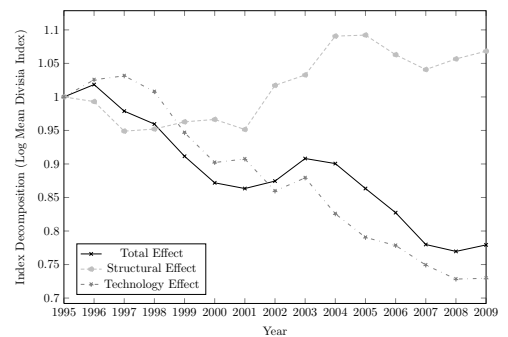

(b) Germany

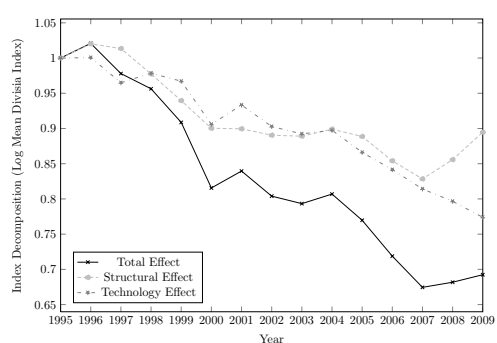

(e) Sweden

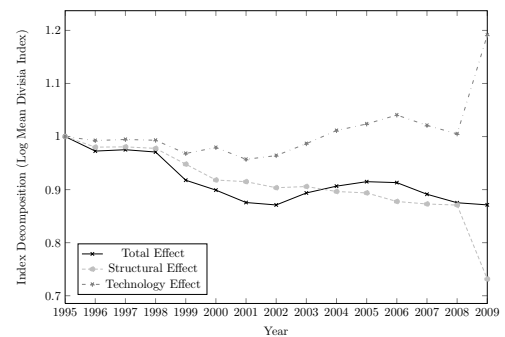

(c) Italy

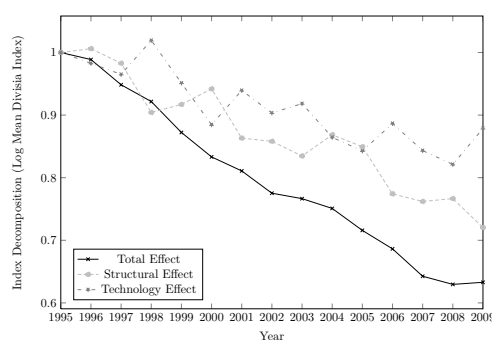

(f) United Kingdom

Figure 4: IDA for the Medium I Block

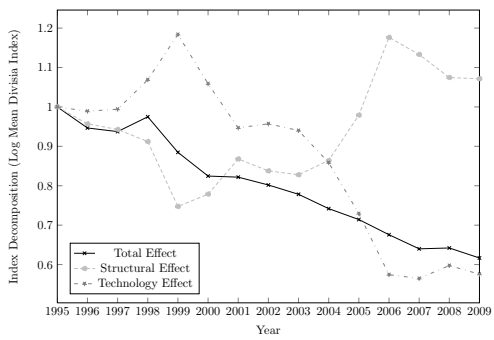

(a) Ireland

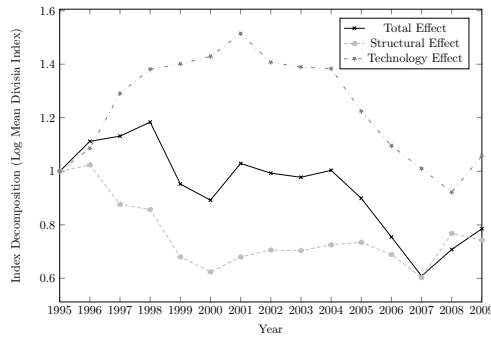

(b) Lithuania

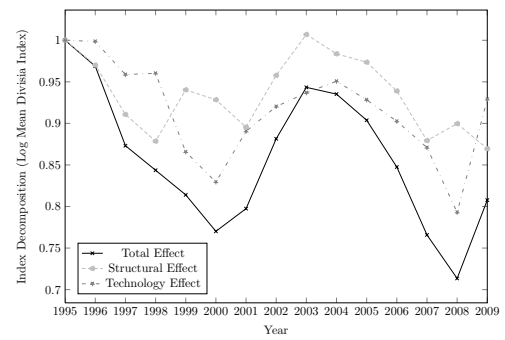

(c) Luxembourg

Figure 5: IDA for the Medium II Block

The indices for the within-country structural events and the technology effects remain stable. The between-country structural effects starts to rise, stating a shift of production towards more energy-intensive countries. The third phase from 2003 to 2009 is characterized by a sharply declining technology effect. It went down from 0.92 to 0.77 . The within-country structural effect remains stable, while the between-country structural effect rises to almost 1.05. Put it otherwise, the energy-intensive sectors remained equal while energy-intensive countries gained in importance. In combination, energy intensity declined in the period from 2003 to 2009 from 0.85 to 0.72 , highlighting the importance of the technology effect. The development of this effect is the key driver for the decline in total energy intensity.

Figure 10 in the appendix depicts the energy intensity evolution by sector between 1995 and 2009. While some sectors experience an increase in energy intensity - the energy intensity of the wood and cork production ("Sector 20") increased by $33 \%$ - most sectors experienced a decrease. The decline ranged from moderate (-3.8\% in the inland transport, or sector "60") to tremendous $(-56.1 \%$ in the coke, refined petroleum and nuclear fuel, or sector "23", an energy-sector correlate). 


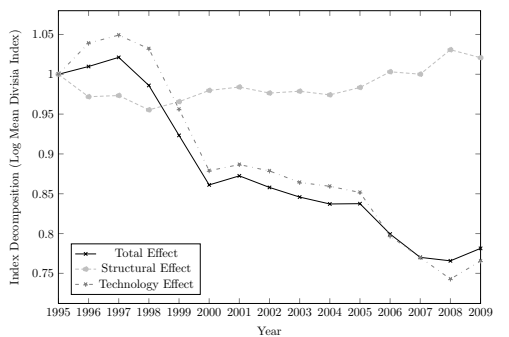

(a) Austria

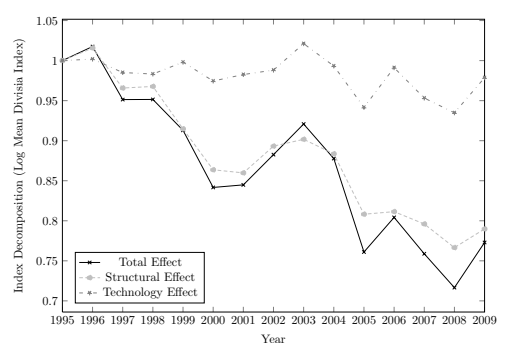

(d) Finland

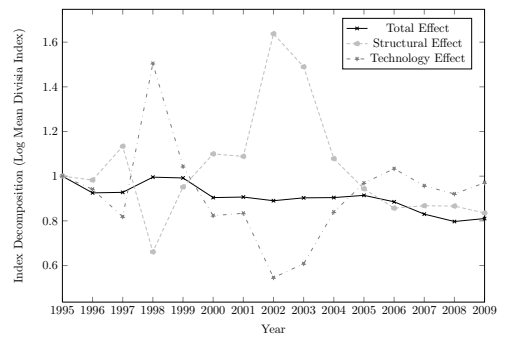

(g) Portugal

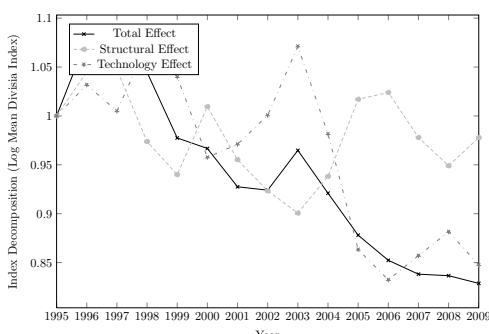

(b) Belgium

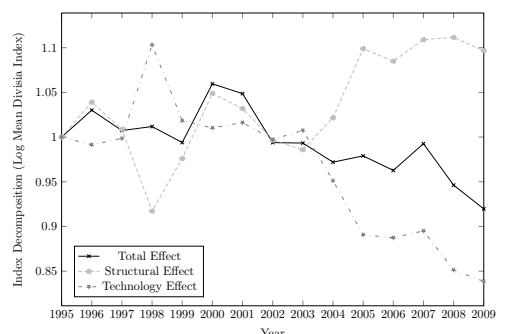

(e) Greece

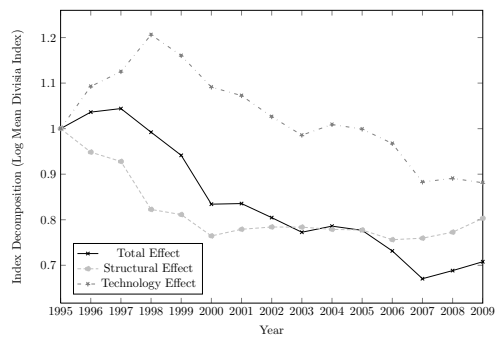

(h) Slovenia

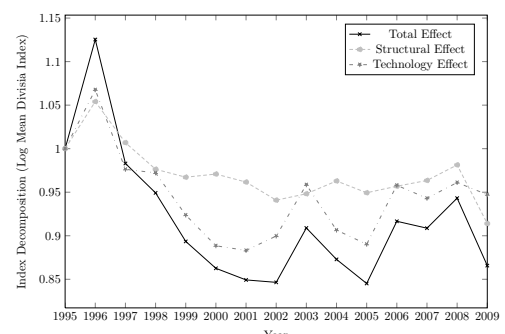

(c) Denmark

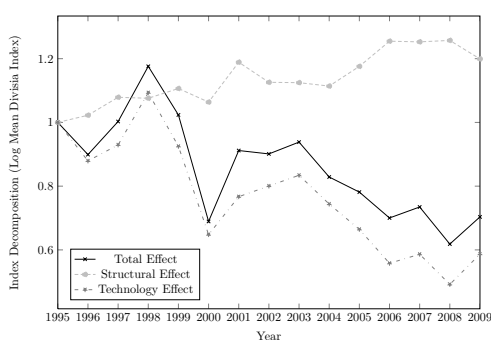

(f) Malta

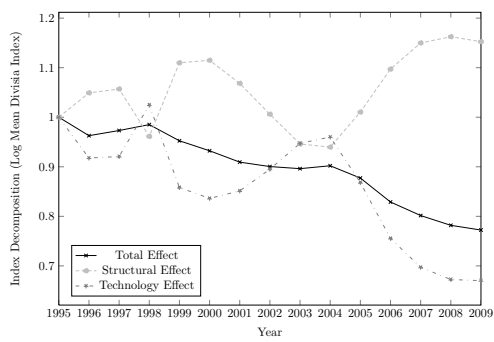

(i) Spain

Figure 6: IDA for the "worst performing" Block

\section{EMPIRICAL INVESTIGATION}

The second part of the paper we use econometric techniques to explain the results of the IDA. We pursue the following empirical strategy. First we use the values obtained for the three indices and create a panel data set for 26 countries - Luxembourg is an outlier and has been excluded - and 12 years (1995 to 2006) ${ }^{15}$ A major drawback of previous studies, as e.g. Metcalf (2008), was that endogeneity problems were not addressed in the econometric strategy. Our final exercise is a counterfactual experiment. We use the observed energy intensity levels in 1995 for each country and multiply them with the obtained index values for the total, the structural effect and the intensity effect. This brings out the level differences between energy intensities for three cases: the actual change (obtained by multiplying the energy intensity in 1995 by the total effect of the index value); the change when technology remains constant; the energy intensities that result when only the structure changes.

\footnotetext{
${ }^{15}$ The data for 2007 to 2009 turned out to be less robust. Hence we excluded it from the empirical investigation.
} 


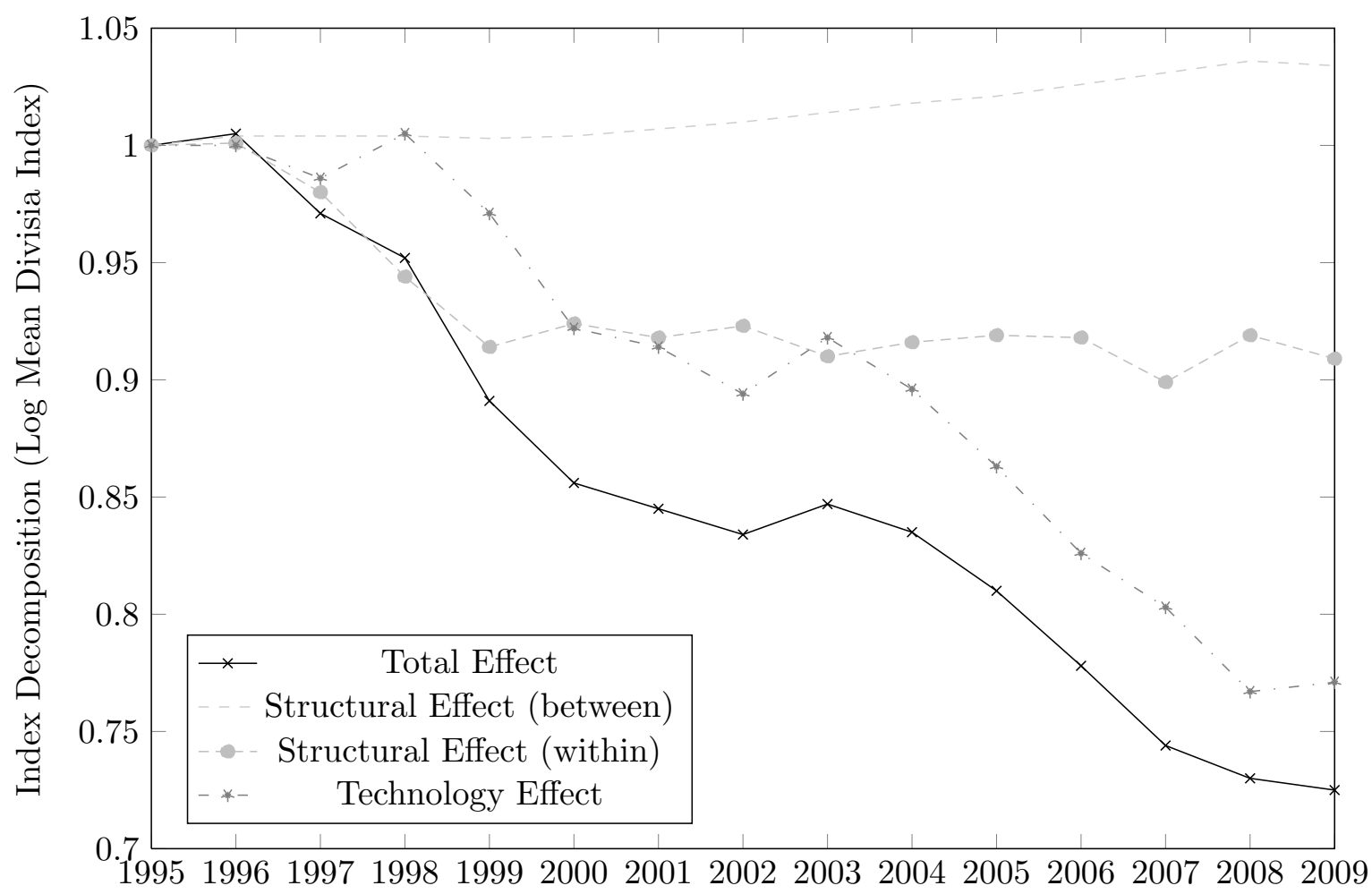

Figure 7: Log Mean Divisia Index Decomposition of Energy Intensity

\section{A. Model AND VARiables}

We estimate three similar panel models by index type for the dependent variables $(x \in$ $\left.\left(D_{\text {Tot }}, D_{\text {Str }}, D_{\text {Int }}\right)\right)$. Our indices control for influential factors, measuring the real decline in energy intensity, the fraction caused by structural change, and the contribution of technology. Our estimation model is expressed by the following equation:

$$
\begin{aligned}
\text { Index }_{x j t}= & =\beta_{0}+\beta \mathbf{X}_{j t}+\delta \mathbf{Z}_{j t}+\varepsilon_{j t} \\
& \text { with } x \in\left(D_{\text {Tot }}, D_{\text {Str }}, D_{\text {Int }}\right) \\
& \beta \mathbf{X}_{j t} \text { as major covariates, } \\
& \delta \mathbf{Z}_{j t} \text { as additional controls, and } \\
& \varepsilon_{j t} \text { as an idiosyncratic error term. }
\end{aligned}
$$


We estimate the following equations:

$$
\begin{aligned}
\text { Index }_{x j t}= & \beta_{0}+\beta_{1} \mathrm{INCOME}_{j t}+\beta_{2} \mathrm{INCOMESQR}_{j t}+\beta_{3} \mathrm{OPEN}_{j t}+ \\
& +\beta_{4} \mathrm{~K} \mathrm{~L}_{j t}+\beta_{5} \mathrm{~K}_{\mathrm{LSQR}_{j t}}+\beta_{6} \mathrm{MANUFACSHARE}_{j t}+ \\
& +\beta_{7} \mathrm{TFP}_{j t}+\beta_{8} \mathrm{ENERGYPRICE}_{j t}+\beta_{9} \mathrm{REGUL}_{j t}+ \\
& +\delta_{1} \mathrm{VINTAGING}_{j t}+\delta_{2} \mathrm{AREA}_{j t}+\delta_{3} \mathrm{POPGROWTH}_{j t}+ \\
& +\delta_{4} \mathrm{LATITUDE}_{j}+\delta_{5} \mathrm{HDD}_{j t}+\delta_{6} \mathrm{COMMUNIST}_{j}+ \\
& +\delta_{7} \operatorname{RENEWABLESHARE}_{j t}+\delta_{8} \mathrm{TREND}_{j t}+\delta_{9} \mathrm{TRENDSQR}_{j t}+ \\
& +\varepsilon_{j t} \\
& \text { with } x \in\left(D_{T o t}, D_{S t r}, D_{\text {Int }}\right)
\end{aligned}
$$

The variables are:

- $\mathrm{INCOME}=$ Instrumented Income per Capita (logarithmic)

- INCOMESQR = Income per Capita squared (logarithmic)

- OPEN = Instrumented Trade Openness (logarithmic)

- $\mathrm{K} / \mathrm{L}=$ Capital to Labor Ratio (logarithmic)

- $\mathrm{K} / \mathrm{LSQR}=$ Capital to Labor Ratio squared (logartihmic)

- MANUFACSHARE = Share of Manufacturing (logarithmic)

- TFP $=$ Estimated Total Factor Productivity (logarithmic and in differences)

- ENERGYPRICE = Price of Energy (logarithmic)

- $\mathrm{REGUL}=$ Index of Energy Efficiency Regulation

- VINTAGING = Capital Vintaging (logarithmic)

- $\mathrm{AREA}=$ Area of Country (logarithmic)

- POPGROWTH = Population Growth Rate

- LATITUDE = Latitude of the Country

- HDD = Heating Degree Days (logarithmic)

- COMMUNIST $=$ Dummy $=1$ for former communist countries

- RENEWABLESHARE = Share of "green" energy in total energy use (logarithmic)

- TREND $=$ Control variable for time trend

- TRENDSQR $=$ Control variable for time trend squared

Before presenting our results, we discuss and justify the variables. Our model consists of 15 variables (and a control for a time trend) attributable to various effects. 


\section{Income}

The variables INCOME and INCOMESQR relate to the Environmental Kuznets Curve (EKC) literature (see Copeland and Taylor (2004) for an excellent theoretical foundation and discussion). The EKC states that there is an inverted U-shaped relationship between income and pollution: a rising income is accompanied by higher levels of pollution up to a point where the relationship inverts and pollution begins to decline with income. The reasons for this trajectory are to be found on the supply side of the economy. Higher levels of income enable better and more efficient technologies on the supply side, as higher levels of income induce a shift in preferences for environmental protection. To avoid potential endogeneity issues, we rely on instrumental variables for income borrowed from the growth literature (Frankel and Rose, 2005).

The estimation equation for the instrument of income is based on Frankel and Rose (2005) and Managi et al. (2009); the estimation results can be found in appendix E

$$
\begin{aligned}
\ln \left(\frac{\text { Real_GDP }}{\text { Pop }}\right)_{j t}= & \alpha_{0}+\alpha_{1} \ln \left(\frac{\text { Real_GDP }}{P o p}\right)_{j t-1}+\alpha_{2} \ln \left(\frac{\text { Real_I }_{G}}{G D P}\right)_{j t} \\
& +\alpha_{3} \ln (n+g+\delta)_{j t}+\alpha_{4} \ln L A B H S_{j t}+\alpha_{4} \ln K_{j t}^{H_{c}} \\
& +\alpha_{4} \ln \left(\frac{K}{L}\right)+\alpha_{4} \ln \text { RealOpenness } s_{j t}+\varepsilon_{j t}
\end{aligned}
$$

Equation IV.13 includes main drivers of income growth. One such influence is the factor accumulation described by the Solow Model. Our approach models human capital in two ways. First we follow Hall and Jones (1999) and Alcalá and Ciccone (2004) and construct average human capital stocks $K_{j t}^{H_{c}}$. Hall and Jones (1999) and Alcalá and Ciccone (2004) use old estimates of return to education and old data on average years of education. We rely on updated measures of return to education provided by Psacharopoulos and Patrinos (2004) and on the newest version of the Barro and Lee educational attainment data (Barro and Lee, 2010). Following Barro and Lee (2010), we interpolate the values between 5-year intervals. The average human capital stock $K_{j t}^{H_{c}}$ in country $j$ is defined as: $K_{j t}^{H_{c}}=\exp \left(\phi\left(S_{c}\right)\right)$, where $S_{c}$ is average schooling and $\phi(\cdot)$ a piecewise linear function capturing estimated social Mincerian returns. We rely on measures for Mincerian returns provided by Psacharopoulos and Patrinos (2004). The yearly rates of return to education cover 16 countries; the data for remaining 11 were obtained by reasoning. One problem that may arise from human capital measures is that high-skilled labor involves investment into human capital and new technologies. But the process of generating new technologies and innovations is inherently uncertain. To cope with this problem, we use the share of high-skilled worker compensation in total worker compensation $(L A B H S)$ provided in the WIOD socioeconomic accounts.

Taking into account the identity of savings and investment, we measure (net) investments (the change of capital stock over time) as the fraction of real GDP saved. The data is provided by Penn World Tables 7.0. We define all real investments as $I / G D P$. The growth of per capita income depends not only on investment in physical capital but also on its depreciation $(\delta)$ and the rate of labor productivity growth $(g)$. As usual, we assume these values are 0.05. Another factor that negatively affects capital accumulation is the rate of population growth $(n)$. We calculate $n$ using the Penn World Tables 7.0. Together $(n+g+\delta)$ are expected to have a 
negative impact on income per capita. Following Managi et al. (2009) we also control for the (logarithmic) capital-to-labor ratio $\frac{K}{L}$ and (logarithmic) real openness RealOpenness.

We expect that the coefficient for INCOME will be positive and the coefficient for INCOMESQR will be negative in the case of $D_{\text {Tot }}$ and $D_{\text {Int }}$. This implies higher index values for higher incomes until the peak of the EKC is reached and then a lower index value for higher rates of income.

\section{Trade}

The next variable is OPEN, defined as the sum of export and imports divided by real gross output in 1995 in US-\$:

$$
\text { Openess }_{j k t}=\frac{X_{j k t}+M_{j k t}}{G O_{j t} R E A L_{j, 1995}} ; \quad j \neq k
$$

The gravity equation for the geography-based bilateral trade share of two countries $j$ and $k$ is borrowed from the work of Frankel and Romer (1999) and Frankel and Rose (2005):

$$
\begin{aligned}
\ln \text { Openess }_{j k t}= & \gamma_{0}+\gamma_{1} \ln \text { Distance }_{j k}+\gamma_{2} \ln \text { Pop }_{j t}+\gamma_{3} \ln \text { Pop }_{k t} \\
& +\gamma_{4} \ln \text { Area }_{j t}+\gamma_{5} \ln \text { Area }_{k t}+\gamma_{6}\left(L L_{j t}+L L_{k t}\right)+\gamma_{7} C B_{j k t} \\
& +\gamma_{8} C B_{j k t} \ln \text { Distance }_{j k t}+\gamma_{9} C B_{j k t} \ln \text { Pop }_{j t}+\gamma_{10} C B_{j k t} \ln \text { Pop }_{k t} \\
& +\gamma_{11} C B_{j k t} \ln \text { Area }_{j t}+\gamma_{12} C B_{j k t} \ln \text { Area }_{k t}+\gamma_{13} C B_{j k t}\left(L L_{j t}+L L_{k t}\right)+\varepsilon_{j k t}
\end{aligned}
$$

The regressor $D_{j k t}$ represents the geographic distance between the capitals of the two trade partners $j$ and $k$. $P o p_{j t}$ and $P o p_{k t}$ are measures of population in countries $j$ and $k$, respectively. In contrast to Frankel and Romer (1999), the measures do not cover the economically active population on account of missing data for some countries in the Penn World Tables. Area $a_{j t}$ and Area $_{k t}$ are controls for the size of two countries; $L L_{j t}$ and $L L_{k t}$ are dummies measuring whether the countries are landlocked. $L L_{j t}+L L_{k t}$ is the common landlocked dummy, which summarizes dummies representing landlocked status. The variable $C B_{j k t}$ is a dummy that assumes the value of 1 when trade partners share a common border. The common border dummy is interacted with other explanatory variables to capture trade between neighboring countries more accurately. The equation is estimated by means of least squares, using the bilateral trade data for all countries included in the WIOD. The geographical information was obtained from the CIA World Fact Book and from the CEEPI Gravity Data Set (Meyer, 2011). After estimating the (first stage) regression to construct the instrument for trade openness, we aggregate the fitted values across all bilateral trade partners. The aggregation yields a given country's trade openness adjusted according to output-based PPPs. The aggregation method is presented in equation D21.

$$
\text { Openess }_{j t}=\sum_{j \neq k} e^{\hat{\boldsymbol{\gamma}}^{\prime} \boldsymbol{X}_{j k t}}
$$

The vector $\gamma$ represents the coefficients in equation IV.15 whereas the vector $\boldsymbol{X}_{j k t}$ stands for the right-hand side variables in equation IV.15. From the first regression on, fitted values were used to predict trade openness. The results of the main regression are shown in Table 7 . We had to run the regression for each year to get meaningful data because each geography variable 
is remains the same over time. Consequently, treating trade flows as a single observation would yield almost constant trade openness observations. The only way to solve the problem is to run the regression individually for each year. This procedure produces the correct predicted trade openness values with time variation - values we later need for our instruments. ${ }^{16}$

As Antweiler et al. (2001) demonstrate in their seminal paper, trade can have a significant and positive impact on the environment through its effects on income and economic composition. And when it does, we can expect that trade will also have a significant indirect effect on the economy's energy intensity. Accordingly, we expect the OPEN coefficient to be negative for all three indicators.

\section{Capital-to-Labor Ratio and Manufacturing Share}

The capital to labor ratio $\mathrm{K} / \mathrm{L}$ is also relevant for the structure of the economy under investigation. We adopt the assumption of Antweiler et al. (2001) that greater capital intensity correlates with greater pollution and energy use (see also Cole and Elliott (2003) and Cole (2006) for further evidence). The WIOD has sectoral estimates for physical capital stocks for all countries and periods. These estimates allow us to test the hypothesis that an increasing capitalto-labor ratio (an indirect measure of structural change) results in increasing energy intensity. We calculate the sample mean of the capital-to-labor ratio and then use relative capital-to-labor ratios. We believe that this concept is superior to Metcalf's, for it accounts not only for structural change but also for comparative advantages between countries. The correlation between total energy use and capital intensity (measured in physical capital stock per working hour) is 0.44 and statistically significant on the $1 \%$ level for our 27-country sample. We expect a negative coefficient for the $\mathrm{K} / \mathrm{L}$ variable for $D_{\text {Str }}$. Another important control for structural change is the share of the secondary (manufacturing) block in an economy. We subtract the gross out of agriculture, mining and services from total gross output and use this as the share of manufacturing industries (MANUFACSHARE).

\section{Total Factor Productivity}

The next variable is the estimated total factor productivity (TFP). Syverson (2011) reports in his survey that even within U.S. four-digit SIC industries, the (average) difference in logarithmic multifactor productivity between an industry's $90^{\text {th }}$ and $10^{\text {th }}$ percentile plants is .651 , resulting in a TFP ratio of $e^{.651}=1.92$. That means that, even within a single four-digit SIC industry in a single country, the $90^{\text {th }}$ percentile of the productivity distribution produces almost twice as much output with the same inputs as the $10^{\text {th }}$ percentile plant. Comin et al. (2006) investigate direct measures of technology adoption for more than 75 different technologies and demonstrate that the cross-country differences in technology are roughly four times larger than cross-country differences in income per capita and that technology is positively correlated to income per capita. Thus, cross-country variation in TFP is almost solely determined by cross-country variation in physical technology. As the European Union is a much more heterogeneous economic environment than the United States, we argue that differences in total factor productivity growth are (a) substantial by themselves and (b) have a substantial impact on energy utilization. We rely on a

\footnotetext{
${ }^{16}$ Sascha Rexhäuser offered us valuable insight about the procedure.
} 
standard measure for gross-output-based TFP as presented in Hsieh and Klenow (2010)..$^{17}$ Level accounting can be interpreted as the cousin of the traditional growth accounting introduced by Robert Solow. Comparison studies of labor productivity often define the United States as the technology leader and then measure the distance between other countries and this reference value. Because we are interested in changes in energy use technology, we use the country with the secondlowest aggregate energy intensity in 1995 as the reference country (Austria and Luxembourg had very similar here. We made an arbitrary decision for Austria). To estimate the total factor productivity we use the gross-output and capital-to-output ratios from the WIOD. We assume a share of capital of 0.3. To control for human capital, we combine these data with the updated Barro and Lee dataset on educational attainment and information on Mincerian returns to education provided by Psacharopoulos and Patrinos (2004).18 Our estimation equation for TFP builds on Hall and Jones (1999); Alcalá and Ciccone (2004) and Hsieh and Klenow (2010) and takes the form:

$$
\operatorname{TFP}_{j t}=\frac{\text { rgdpwok }}{\left.\left(\frac{\mathrm{K}}{\mathrm{GO}} \cdot \operatorname{rgdpwok}\right)^{\alpha} \cdot \exp (\Theta \cdot \text { SchoolingYears })\right)^{1-\alpha}}
$$

We combine multiple data sources to obtain our TFP estimate. We start with real gdp per worker from the Penn World Tables 7.0. $K$ over $G O$ describes the relationship of physical capital stock to gross output as recorded in the WIOD. $\alpha$ refers to the share of capital compensation and is taken to be 0.3 , which is in line with common assumptions. $\Theta$ stands for Mincerian returns to education, again taken from Psacharopoulos and Patrinos (2004). We combine this information with our interpolated version of the Barro and Lee dataset, thus correcting the TFP measure for human capital formation. To see how our measure for total factor performs, we calculated the growth rates of TFP and instrumented income per capita and plotted them. The result is presented in Figures $8 \mathrm{a}$ and $8 \mathrm{~b}$

We include the TFP variable expressed in logs. We expect that the coefficient will be negative in the case of $D_{T o t}$ and $D_{\text {Int }}$, implying a lower index value for higher rates of total factor productivity. The effect on the economic structure is unknown ex ante.

\section{Regulation and Prices}

The next variables are prices (ENERGYPRICE) and regulatory measures (REGUL). We used the annual average energy prices as a measure for price induced changes in technology or economic structure. The data source is Eurostat 19 We also collected data on environmental regulation in the European Union for the time period under consideration. To account for various climate and environmental policies, we made use of the Policies and Measures Databases provided by the International Energy Agency (IEA, 2012). They consist of three different databases: Global Renewable Energy, Energy Efficiency, and Policy Measures Addressing Climate Change.

\footnotetext{
${ }^{17}$ Citing Hsieh and Klenow $(2010)$ neglects many other important contributions dealing with multifactor productivity. For more here, see the surveys by Caselli (2005) and Syverson (2011).

${ }_{18}$ Psacharopoulos and Patrinos (2004) provides detailed information on Mincerian returns for 16 of our 27 countries. For the remaining 11 countries, we use values from countries with similar economic and political structures. For example, we apply the $6.4 \%$ p.a. given for Belgium to the Netherlands.

${ }^{19}$ Of the 405 data points (spanning 27 countries and 15 years), 76 were missing, mostly from 1998 . To create proxies for the absent data, we interpolated the values from 1997 and 1999.
} 


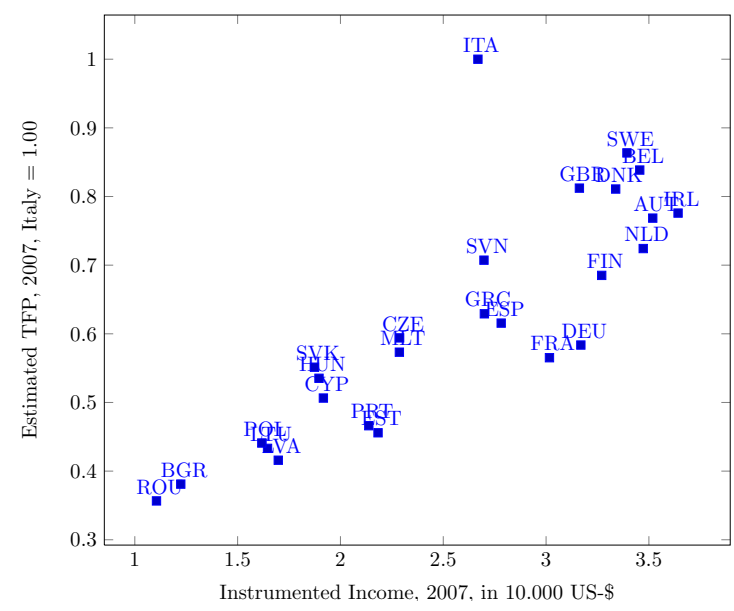

(a) TFP vs. Income

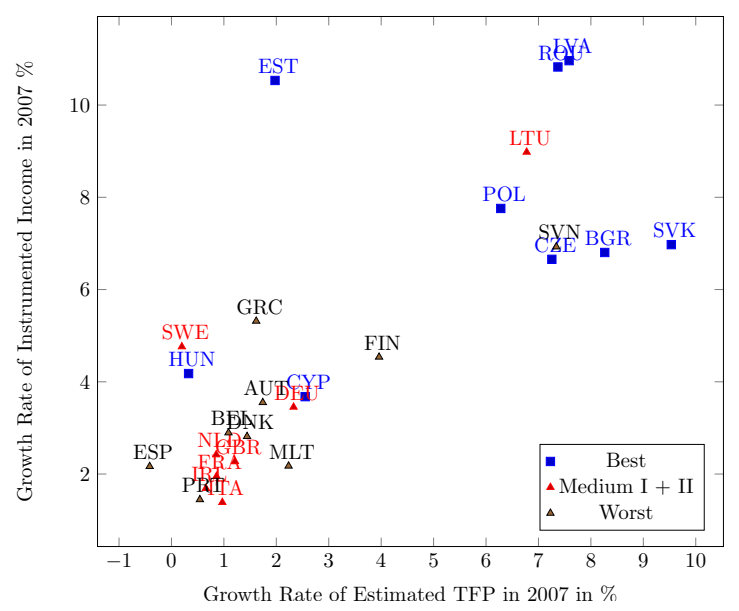

(b) TFP-Growth vs. Income-Growth

Figure 8: TFP vs. Instrumented Income and TFP-Growth vs. Income-Growth

Altogether, these databases contain data on more than 3,600 policies and on all types of policy measures going back to 1973 for some 50 countries. The information recorded in the databases encompasses indicators such as targeted sector (e.g. electricity, appliances, buildings, industry), technology (with particular emphasis on renewable technologies), jurisdiction (whether the policy is implemented on a subnational, national or international level) and policy type (e.g. R \& D investments, standards, taxes, permits).

We prepared the data in the following way. First, we merged the databases, creating a common ground for the regulatory stringency index. Second, we broke down policies containing multiple indicators (e.g. solar PV/wind/bioenergy and R \& D investments/standards) or policies assigned to multiple sectors into single policy measures. Sometimes this meant dropping observations when our manual search found no specific information or indicator for a database entry. We also dropped observations to avoid double counting, as some policies are reported in more than one of the original databases. This left us with approximately 3,200 policy measures for the analysis. Third, for the policy types and targeted technologies within the energy sector we constructed multi-level structures in which we assigned the types and technologies appearing in the original database to higher-level instances ${ }^{20}$

We apply a weighting scheme for policy to construct our regulatory index. The various energy policies can be subdivided into three different groups, each characterizing a different level of stringency. First, there are technology-oriented measures such as voluntary approaches and the subsidization of $\mathrm{R} \& \mathrm{D}$. These are the least stringent measures in the construction of our regulation index. The second group consists of command-and-control based policies such as standards and quotas. And finally, there are market-based instruments, which we classify as most stringent. Though we conducted sensitivity analysis with various weighting schemes,

\footnotetext{
${ }^{20}$ We thank Enrica De Cian, Elena Verdolini and Sebastian Voigt for providing us with their data.
} 
the results changed neither qualitatively nor quantitatively. Our index was constructed by the following formula:

$$
\begin{aligned}
R E G U L_{j t}= & \omega \sum T E C H_{j t}+\theta \sum C O M M A N D_{j t}+\sum \phi M A R K E T_{j t} \\
& \text { with } j \in 1, \ldots, 27, \\
& t \in 1995, \ldots, 2006 \\
& \omega, \theta \text { and } \phi \text { as weights }
\end{aligned}
$$$$
\text { and TECHN, COMMAND and MARKET as policy types. }
$$

For our main estimations we used 0.5 for $\omega, 0.8$ for $\theta$ and 1.0 for $\phi .21$ Figure 9 illustrates the development of our reference energy efficiency regulation index for four countries: Germany, Sweden, Poland and Slovenia. Two observations are remarkable. First, the index value is for all mature European countries whose energy efficiency is higher than that of Eastern European countries. And second, an energy efficiency trend can be found for Western countries but not for Eastern. These two observations hold true for the entire sample and will be important for the interpretation of the estimation results later in the paper.

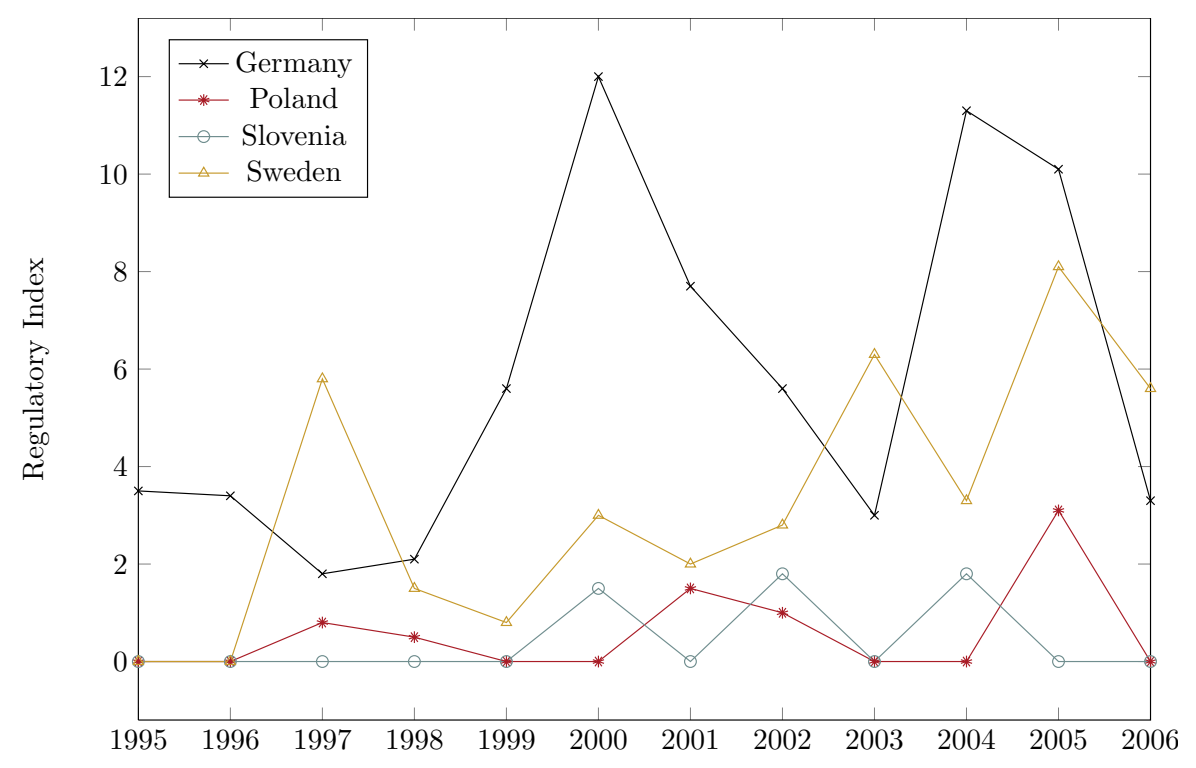

Figure 9: Regulatory index for four countries

\section{Further Controls}

We also included several other control variables in our regression model. VINTAGING captures the national differences in capital stock vintaging (Source: WIOD). VINTAGING is included in the model as the ratio of investment to capital stock. The effect may be positive since fast growing countries may have newer capital stock, which uses less energy and is hence more efficient. AREA is the geographical area of a country in $\mathrm{km}^{2}$ taken from the CIA World Fact Book. It captures the effects of potential economies of scale (Sala-i-Martin, 1997ab). Larger

\footnotetext{
${ }^{21}$ We used vastly different weighting schemes, ranging from equal weights to situations in which only commandand-control policies mattered (i.e. where $\omega$ and $\phi$ were 0 ). The results are insensitive to the choice of the weights.
} 
countries may need larger but more efficient power plants. On the other hand, these countries may need larger power grids, which have lower efficiency. POPGROWTH is the population growth rate (see PWT 7.0). It captures the effect of a growing population on energy intensity, as "fast growing states may be adding infrastructure that is more energy efficient than slow growing states" (Metcalf, 2008, p. 9). Furthermore, as Kormendi and Meguire (1985) pointed out, a fast growing population may hamper economic growth and therefore lower income per capita and alter environmental preferences. The variable LATITUDE is the geographical latitude of a country (see CIA World Fact Book) and might be an important driver of energy intensity to be accounted for. The rationale behind the LATITUDE variable is twofold. First, southern European countries such as Italy and Spain have a larger demand for power plant cooling and air conditioning (in sectors outside the private sector) than central European countries. Conversely, northern European countries such as Finland and Sweden have a larger demand for heating and lighting than the rest of Europe. By including the LATITUDE of a country we control for this effect. The second rationale behind the LATITUDE variable is that geographical latitude may be a determinant of long-run economic development and growth (Rodrik et al., 2004). Accordingly, it can also affect the environmental preferences expressed by the POPGROWTH variable. In line with Metcalf (2008) we included heating demand days to control for climate factors.

The COMMUNIST variable is a dummy variable that equals 1 when a country was part of the former Soviet block. The fall of the Iron Curtain brought with it a tremendous structural break, rendering the old capital stock in these countries nearly worthless. In this case, the vintage capital structure would be different than that of the "old" European countries. Another consideration is the "low-hanging fruits" for energy efficiency in the former Soviet countries. Our COMMUNIST dummy captures these effects. We also introduced a control for the regulation index (REGUL). Because the regulation index measures current activities in energy efficiency policy, it might omit past efforts. Hence, we calculate the share of renewable energy sources in energy efficiency policy using information on 26 energy carriers from WIOD. The variable RENEWABLESHARE captures the efforts of past regulatory measures and accounts for "natural" endowments in renewable energy (such as those found in Sweden). Finally, we have included a time trend in our regressions to capture independent influential factors we did not account for.

\section{B. RESULTS AND INTERPRETATION}

\section{Empirical Approach}

Our panel data sets afford two principle approaches for econometric modeling that can be applied to any of our models: fixed-effects estimators and random-effects estimators. The key advantage of using the fixed-effects estimator is that it typically includes dummy variables that capture the influence of time-invariant, unobservable factors - topography, other country-specific characteristics - that might be correlated with explanatory variables. The result: consistent estimates. By contrast, the random-effects estimator assumes that a correlation with the regressors is 0 . When this assumption is met, the random-effects estimator is more efficient than the fixed-effects estimator. If this assumption is violated, however, the estimates will be biased. We run both fixed- and random-effects estimators and apply the standard Hausman test to validate which type of estimator is more appropriate (Wooldridge, 2002). Notwithstanding, the figures 
for the index decomposition might depict a kind of spurious correlation. Thus, we carry out unit root tests for panel data. Herein, we focus on the Fisher-type Augmented Dickey Fuller test for unit roots in panel data (based on Dickey and Fuller, 1979). The tests indicate a unit root in the technology effect index variable, the income per capita variable and the heating degree days variable. All other variables do not have unit roots according to the test results.

II. Results of our Core Model: Index Values as Dependent Variables

Table 1 presents the results of the fixed-effects estimation with the three indices for total effects, structural effects and technology effects as dependent variables. Our sample consists of 338 observations spanning 26 countries (Luxembourg is again excluded) and the years 1995 to 2007. We have omitted the years 2008 and 2009 as these years are distorted by the financial crisis. Recall that time-invariant explanatory variables such as AREA cannot be identified due to the presence of country fixed effects.

\begin{tabular}{|c|c|c|c|}
\hline \multirow[b]{2}{*}{ Index } & \multicolumn{3}{|c|}{ Fixed Effects Results } \\
\hline & TOTAL & STRUCTURAL & TECHNOLOGY \\
\hline INCOME $(\log )$ & $\begin{array}{l}-0.242 \\
(0.227)\end{array}$ & $\begin{array}{c}1.196^{* * *} \\
(0.410)\end{array}$ & $\begin{array}{c}-0.874^{* *} \\
(0.398)\end{array}$ \\
\hline INCOMESQR (log) & $\begin{array}{c}0.080^{* *} \\
(0.039)\end{array}$ & $\begin{array}{c}-0.138^{* *} \\
(0.070)\end{array}$ & $\begin{array}{c}0.142^{* *} \\
(0.068)\end{array}$ \\
\hline OPEN $(\log )$ & $\begin{array}{c}0.085^{* *} \\
(0.039)\end{array}$ & $\begin{array}{l}0.128^{*} \\
(0.071)\end{array}$ & $\begin{array}{l}-0.100 \\
(0.069)\end{array}$ \\
\hline Relative KL (log) & $\begin{array}{l}0.206 \\
(0.201)\end{array}$ & $\begin{array}{c}0.255 \\
(0.363)\end{array}$ & $\begin{array}{l}-0.108 \\
(0.353)\end{array}$ \\
\hline Relative KLSQR (log) & $\begin{array}{l}-0.053 \\
(0.071)\end{array}$ & $\begin{array}{c}0.078 \\
(0.128)\end{array}$ & $\begin{array}{l}-0.076 \\
(0.125)\end{array}$ \\
\hline MANUFACSHARE (log) & $\begin{array}{c}-0.202^{* * * *} \\
(0.050)\end{array}$ & $\begin{array}{c}-0.378^{* * *} \\
(0.091)\end{array}$ & $\begin{array}{c}0.366^{* * *} \\
(0.089)\end{array}$ \\
\hline TFP $(\log )$ & $\begin{array}{c}-0.478^{* * *} \\
(0.111)\end{array}$ & $\begin{array}{c}-0.879 * * * \\
(0.201)\end{array}$ & $\begin{array}{l}-0.056 \\
(0.195)\end{array}$ \\
\hline ENERGYPRICE (log) & $\begin{array}{l}-0.018 \\
(0.026)\end{array}$ & $\begin{array}{c}-0.107^{* *} \\
(0.047)\end{array}$ & $\begin{array}{c}0.107^{* *} \\
(0.045)\end{array}$ \\
\hline REGULATION (log) & $\begin{array}{l}-0.001 \\
(0.005)\end{array}$ & $\begin{array}{l}-0.007 \\
(0.009)\end{array}$ & $\begin{array}{c}0.005 \\
(0.009)\end{array}$ \\
\hline VINTAGING (log) & $\begin{array}{c}0.020 \\
(0.036)\end{array}$ & $\begin{array}{l}0.124^{*} \\
(0.065)\end{array}$ & $\begin{array}{l}-0.001 \\
(0.063)\end{array}$ \\
\hline POPGROWTH & $\begin{array}{c}-0.069 * * * \\
(0.016)\end{array}$ & $\begin{array}{l}-0.054^{*} \\
(0.029)\end{array}$ & $\begin{array}{l}-0.034 \\
(0.028)\end{array}$ \\
\hline HDD (log) & $\begin{array}{c}0.204^{* * *} \\
(0.045)\end{array}$ & $\begin{array}{c}0.010 \\
(0.081)\end{array}$ & $\begin{array}{c}0.156^{* *} \\
(0.079)\end{array}$ \\
\hline RENEWABLESHARE & $\begin{array}{l}-0.199 \\
(0.273)\end{array}$ & $\begin{array}{c}0.174 \\
(0.495) \\
\end{array}$ & $\begin{array}{l}-0.490 \\
(0.480)\end{array}$ \\
\hline Time Fixed Effects & Yes & Yes & Yes \\
\hline Observations & 338 & 338 & 338 \\
\hline$R^{2}$ (within) & 0.819 & 0.345 & 0.349 \\
\hline F-Statistic & 89.507 & 10.417 & 10.637 \\
\hline Hausman-Test & $30.22^{* * *}$ & $29.98^{* * *}$ & $25.23^{* *}$ \\
\hline
\end{tabular}

Table 1: Fixed Effects results: Indexes as Dependent Variables

The total effect increases with INCOME, but the relationship follows an inverted $\mathrm{u}$-shape course. The estimated turning point is at 9.236 US- $\$$, a value in the $10 \%$ percentile. The corresponding turning point of the structural effect is an income of 46,746 US-\$. Because the coefficient on INCOME is negative for the technology effect, the decrease in energy intensity 
happens via the efficiency channel. We conclude that scale effects are dominated by technology effects, as a rising INCOME lowers aggregate energy intensities. This could be due to an increase in environmental regulation (preference shifts) or the usage of more advanced technologies.

An increasing OPENNESS variable - an increasing participation in international trade lowers, ceteris paribus, the total energy intensity index. Because the coefficient for the structural effect is positive (implying higher values for the structural effect), the decrease in the total effect is once again explained by the efficiency channel. The corresponding coefficient is even higher and statistically significant on the $1 \%$-level. This could be due to an outsourcing of energy-intensive industries or imports of improved technology from abroad.

The total effect increases as the relative capital-to-labor ratio grows. The calculated turning point is a capital-to-labor ratio of 3.79, a value above the maximum level of 3.59 for the capitalto-labor ratio in the sample (note that the squared term is not significant). The effect of an increasing capital-to-labor ratio is not significant in the regressions for the other two index values. Hence, we can confirm that capital and energy complement each other in the short run. This finding is supported by the coefficient of VINTAGING. Countries with higher investment rates tend to have higher energy intensity. Most important is the TFP variable, which represents advantages in technology. Countries with higher growth rates in total factor productivity have, ceteris paribus, lower energy intensities. Surprisingly, this occurs via the structural channel. Our control variable for energy efficiency regulation is not significant in any model.

To summarize, the variables we declared important for technological change (INCOME, INCOMESQR and TFP) play the most crucial role in driving the decline in energy intensity, though structural change factors (as e.g. OPEN, KL and KLSQR) are also relevant.

III. Results of our Core Model: Real Values as Dependent Variables

Our final empirical exercise is combining the energy intensity in 1995 with the obtained index values for the three effects. By doing this, we take the level differences between energy intensities into account. Hence, our dependent variables are no longer index values, but the three logarithmic energy intensities. Table 2 summarizes the results of running our core model on the three energy intensity levels: 


\begin{tabular}{|c|c|c|c|}
\hline \multirow[b]{2}{*}{ Index } & \multicolumn{3}{|c|}{ Fixed Effects Results } \\
\hline & TOTAL & STRUCTURAL & TECHNOLOGY \\
\hline \multirow[t]{2}{*}{ INCOME (log) } & $-0.476^{*}$ & $1.185^{* * *}$ & $-1.718^{* * *}$ \\
\hline & $(0.282)$ & $(0.436)$ & $(0.455)$ \\
\hline \multirow[t]{2}{*}{ INCOMESQR (log) } & $0.118^{* *}$ & $-0.144^{*}$ & $0.275^{* * *}$ \\
\hline & $(0.048)$ & $(0.074)$ & $(0.078)$ \\
\hline \multirow[t]{2}{*}{ OPEN $(\log )$} & $0.096^{* *}$ & $0.293 * * *$ & $-0.203^{* *}$ \\
\hline & $(0.049)$ & $(0.075)$ & $(0.078)$ \\
\hline \multirow[t]{2}{*}{ Relative KL (log) } & 0.293 & 0.262 & 0.047 \\
\hline & $(0.249)$ & $(0.386)$ & $(0.403)$ \\
\hline \multirow[t]{2}{*}{ Relative KLSQR (log) } & -0.085 & 0.113 & -0.206 \\
\hline & $(0.088)$ & $(0.136)$ & $(0.142)$ \\
\hline \multirow[t]{2}{*}{ MANUFACSHARE (log) } & $-0.282 * * *$ & $-0.727 * * *$ & $0.446^{* * *}$ \\
\hline & $(0.063)$ & $(0.097)$ & $(0.101)$ \\
\hline \multirow[t]{2}{*}{ TFP (log) } & $-0.661 * * *$ & $-0.908 * * *$ & 0.239 \\
\hline & $(0.138)$ & $(0.213)$ & $(0.223)$ \\
\hline \multirow[t]{2}{*}{ ENERGYPRICE (log) } & -0.041 & $-0.151^{* * *}$ & $0.114^{* *}$ \\
\hline & $(0.032)$ & $(0.050)$ & $(0.052)$ \\
\hline \multirow[t]{2}{*}{ REGULATION (log) } & -0.001 & -0.006 & 0.005 \\
\hline & $(0.006)$ & $(0.010)$ & $(0.010)$ \\
\hline \multirow[t]{2}{*}{ VINTAGING (log) } & 0.023 & 0.107 & -0.083 \\
\hline & $(0.045)$ & $(0.069)$ & $(0.072)$ \\
\hline \multirow[t]{2}{*}{ POPGROWTH } & $-0.090 * * *$ & $-0.062^{* *}$ & -0.028 \\
\hline & $(0.020)$ & $(0.030)$ & $(0.032)$ \\
\hline \multirow[t]{2}{*}{ HDD (log) } & $0.230 * * *$ & 0.031 & $0.194^{* *}$ \\
\hline & $(0.056)$ & $(0.086)$ & $(0.090)$ \\
\hline \multirow[t]{2}{*}{ RENEWABLESHARE } & -0.444 & 0.061 & -0.517 \\
\hline & $(0.339)$ & $(0.525)$ & $(0.549)$ \\
\hline Time Fixed Effects & Yes & Yes & Yes \\
\hline Observations & 338 & 338 & 338 \\
\hline$R^{2}$ (within) & 0.834 & 0.485 & 0.421 \\
\hline F-Statistic & 99.307 & 18.662 & 14.389 \\
\hline
\end{tabular}

Table 2: Fixed Effects results: Levels as Dependent Variables

Regressing levels on the explanatory variables confirms our previous results. Most of the estimated parameters retain their direction and their significance. INCOME and INCOMESQR, for example, have significant impacts on all three effects. Their magnitude is stronger when explaining the total and the technology effect in levels than when explaining them in indexes. Our measure of openness remains highly significant, as do MANUFACSHARE and TFP.

\section{Conclusion}

The purpose of this study is to explain the forces driving improvements in energy intensity in the European Union between 1995 and 2009, in times with and without climate policy and economic turbulence. It contributes to the large literature on energy decomposition analysis in three ways. First, it is the only analysis of energy intensity at country and sectoral levels for the entire European Union using a perfect decomposition methodology. It employs a novel socio-economic database escorted by environmental satellite accounts allowing us to construct measures of energy intensity for 34 sectors in 27 countries. Second, this study uses econometric methods to identify the drivers of changes in efficiency and economic activity indexes. Third, it carefully addresses endogeneity issues, an aspect that has been ignored by previous studies. 
We decomposed energy intensities into structural and technology effects in order to examine what share of temporal variation is due to changes in energy efficiency and is thus replicable, and what share is based merely on structural changes of the economy. We grouped the countries in four main clusters with respect to gross output and energy use growth rates. Despite the regional variations, the general result is that in most countries both the technology and structural indexes improved over the time horizon considered. In some countries energy efficiency improved substantially, further below the already low initial levels in 1995. In this case, both the structural and technology effects work in the direction of an energy efficient economy.

The aggregate and country-level decompositions of energy intensity we have presented in this paper suggest very different conclusions. We find that technological advances are a main explanatory factor for energy intensity improvement in Europe, suggesting a general transition towards more efficient means of production. Conversely, our country-level analysis shows that the heterogeneity across countries is high and that a common pattern could not have been singled out without an empirical investigation. Countries' performances in terms of the structural and technology component differ independently of the economy's level of development or initial level of energy efficiency. Among the different economies in our sample, some large countries where the role of the technology component was high include, among others, Germany, France, Spain and Poland. This is an optimistic conclusion, as it means that the development is replicable in less developed regions such as India or China. Although structural change is nearly as important - no surprise after the fall of the Iron Curtain - technological progress is the key driving force. 


\section{REFERENCES}

Alcalá, F., Ciccone, A. (2004): Trade and productivity, in: The Quarterly Journal of Economics, Vol. 119, No. 2, pp. 613-646.

Alcantara, V., Duarte, R. (2004): Comparison of energy intensities in European Union countries. Results of a structural decomposition analysis, in: Energy Policy, Vol. 32, pp. 177189.

ANG, B.W. (1994): Decomposition of industrial energy consumption, in: Energy Economics, Vol. 16, pp. 163-174.

ANG, B.W., Chor, K.H. (1997): Decomposition of aggregate energy and gas emission intensitites for industry: a refined Divisia index method, in: The Energy Journal, Vol. 18, pp. 59-73.

ANg, B.W., Zhang, F.Q., Choi, K.-H. (1998): Factorizing changes in energy and environmental indicators through decomposition, in: Energy, Vol. 23, pp. 489-495.

ANG, B.W., Zhang, F.Q. (2000): A survey of index decomposition analysis in energy and environmental studies, in: Energy, Vol. 25, pp. 1149-1176.

ANG, B.W. (2004): Decomposition analysis for policymaking in energy: which is the preferred method?, in: Energy Economics, Vol. 32, pp. 1131-1139.

ANG, B.W., LIU, N. (2007): Energy decomposition analysis: IEA model versus other methods, in: Energy Policy, Vol. 35, pp. 1426-1432.

ANG, B.W., Mu, A.R., ZHOU, P. (2010): Accounting frameworks for tracking energy efficiency trends, in: Energy Economics, Vol. 32, pp. 1209-1219.

Antweiler, W., Copeland, B.R., Taylor, M.S. (2001): Is Free Trade Good for the Environment?, in: The American Economic Review, Vol. 91, No. 4, pp. 877-908.

Balezentisa, A., Balezentisa, T., Streimikienec, D. (2011): The energy intensity in Lithuania during 1995-2009: A LMDI approach, in: Energy Policy, Vol. 39, No. 11, pp. 7322-7334.

Bartelsman, E.J., Doms, M. (2000): Understanding Productivity: Lessons from Longitudinal Microdata, in: Journal of Economic Literature, Vol. 38, No. 3, pp. 569-594.

Barro, R., LeE, J.-W. (2010): A New Data Set of Educational Attainment in the World, 1950-2010, in: NBER Working Paper, No. 15902.

Boyd, G., McDonald, J.F., Ross M., Hansont, D.A. (2010): Separating the Changing Composition of U.S. Manufacturing Production from Energy Efficiency Improvements: A Divisia Index Approach, in: The Energy Journal, Vol. 8, pp. 77-96.

BoyD, G.A., Roop, J.M. (2004): A Note on the Fisher Ideal Index Decomposition for Structural Change in Energy Intensity, in: The Energy Journal, Vol. 25, No. 1, pp. 87-101.

CAselli, Francesco (2005): Chapter 9: Accounting for Cross-Country Income Differences, in: Handbook of Economic Growth, Vol. 1, No. 1, pp. 679-741. 
Caselli, F., Coleman, W.J. (2006): The World Technology Frontier, in: The American Economic Review, Vol. 96, No. 3, pp. 499-522.

Chor, K.-H., ANg, B.W. (2012): Attribution of changes in Divisa real energy intensity index - An extension to index decomposition analysis, in: Energy Economics, Vol. 34, pp. 171-176.

Cole, Mathhew A. and Robert J.R. Elliotr (2003): Determining the Trade-Environment Composition Effect: The Role of Capital, Labor and Environmental Regulations, in: Journal of Environmental Economics and Management, Vol. 46, No. 3, pp. 363-383.

Cole, Matthew A. (2006): Does Trade Liberalization Increase National Energy Use?, in: Economics Letters, Vol. 92, No. 1, pp. 108-112.

Comin, D., Hobijn, B., Rovito, E. (2006): Five Facts you Need to Know about Technology Diffusion, in: NBER Working Papers, Nr. 11928.

Copeland, Brian R. and M. Scott TAYlor (2004): Trade, Growth, and the Environment, in: Journal of Economic Lietarture, Vol. 42, No. 1, pp. 7-71.

Cornillie, J., Fankhauser, S. (2004): The energy intensity of transition countries, in: Energy Economics, Vol. 26, pp. 283-295.

Dickey, D. A., Fuller, W. A. (1979): Distribution of the estimators for autoregressive time series with a unit root, in: Journal of the American Statistical Association, Vol. 74, pp. 427431.

DiEWERT, E.W. (1993): Index Numbers, in: Essays in Index Number Theory, Vol. 1, No. 1, Chapter 5, pp. 71-109.

European Commission (2012): Non-Paper of the Services of the European Commission on Energy Efficiency Directive, see: http://ec.europa.eu/energy/efficiency/eed/doc/20120424_ energy_council_non_paper_efficiency_en.pdf.

Fisher-Vanden, K. Jefferson, G.H., LiU, H., TaO, Q. (2004): What is driving China's decline in energy intensity?, in: Resource and Energy Economics, Vol. 26, pp. 77-97.

Frankel, J.A., Romer, D. (1999): Does Trade Cause Growth?, in: The American Economic Review, Vol. 89, No. 3, pp. 379-399

Frankel, J.A., Rose, A.K. (2005): Is Trade Good or Bad for the Environment? Sorting Out the Causality, in: The Review of Economics and Statistics, Vol. 87, No. 1, pp. 85-91.

Grossman, G.M., Krueger A.B. (1991): Environmental Impacts of a North American Free Trade Agreement, in: NBER Working Paper Series, Working Paper No. 3914.

Gurgul, H., LACH L. (2012): The electricity consumption versus economic growth of the Polish economy, in: Energy Economics, Vol. 34, No. 2, pp. 500-510.

Hall, R.E., Jones, C.I. (1999): Why do Some Countries Produce So Much More Output Per Worker than Others?, in: The Quarterly Journal of Economics, Vol. 114, No. 1, pp. 83-116.

Hatzigeorgiou, E., Polatidis, H., Haralambopoulos, D. (2008): CO2 emissions in Greece for 1990-2002: A decomposition analysis and comparison of results using the Arithmetic Mean Divisia Index and Logarithmic Mean Divisia Index techniques, in: Energy, Vol. 33, No. 3, pp. 492-499. 
Heston, A., Summers, R.,Aten B. (2011): Penn World Tables Version 7.0, by: Center for International Comparisons of Production, Income and Prices at the University of Pennsylvania, 2011.

Huntington, H.G. (2010): Structural Change and U.S. Energy Use: Recent Patterns, in: The Energy Journal, Vol. 31, pp. 25-39.

Hsien, C.-T., Klenow, P.J. (2010): Development Accounting, in: American Economic Journal: Macroeconomics, Vol. 2, No. 1, pp. 207-223.

International ENergy Agency (2012): Policies and Measures Databases, in: http://www.iea.org/textbase/pm/index.html.

Jakob, M., Haller, M., Marschinski, R. (2012): Will history repeat itself? Economic convergence and convergence in energy use patterns, in: Energy Economics, Vol. 34, pp. 95104.

KIM, K., and KIM, Y. (2012): International comparison of industrial CO2 emission trends and the energy efficiency paradox utilizing production-based decomposition, in: Energy Economics, Vol. 34, No. 5, pp. 1724-1741.

Kormendi, R., Meguire, P. (1985): Macroeconomic Determinants of Growth: Cross Country Evidence, in: Journal of Monetary Economics, Vol. 16, No. 2, pp. 141-63.

Levinson, A. (2009): Technology, International Trade, and Pollution from US Manufacturing, in: The American Economic Review, Vol. 87, No. 1, pp. 85-91.

Linares, P., Labandeira, X. (2010): Energy Efficiency: Economics and Policy, in: EnergyJournal of Economic Surveys, Vol. 24, No. 3, pp. 573-592.

MA, C., Stern, D.I. (2008): China's changing energy intensity trend: A decomposition analysis, in: Energy Economics, Vol. 30, No. 3, pp. 1037-1053.

Managi, S., Hibiki A., Tsurumi T. (2009): Does Trade Openess Improve Environmental Quality?, in: Journal of Environmental Economics and Management, Vol. 58, No. 3, pp. 346363.

Markandya, A., Pedroso-Galinato A., Streimikiene D. (2006): Energy intensity in transition economies: Is there convergence towards the EU average?, in: Energy Economics, Vol. 28, No. 1, pp. 121-145.

Mendiluce, B., Perez-Arriaga I., Ocañ A C. (2010): Comparison of the evolution of energy intensity in Spain and in the EU15.Why is Spain different?, in: Energy Policy, Vol. 38, pp. 639-645.

Metcalf, G.E. (2008): An Empirical Analysis of Energy Intensity and Its Determinants at the State Level, in: The Energy Journal, Vol. 29, No. 3, pp. 1-25.

Mayer T., and Zignago S. (2011): Notes on CEPII's Distances Measures: The GeoDist Database, CEPII Working Paper No. 2011-25.

Mulder, P., and De Groot, H.L.F. (2012). Structural change and convergence of energy intensity across OECD countries, 1970-2005, in: Energy Economics, Vol. 34, No. 6, pp. 19101921. 
PopovicI, V. (2011): 2010 power generation sector restructuring in Romania - A critical assessment, in: Energy Policy, Vol. 39, No. 3, pp. 1845-1856.

Psacharopoulos, G., Patrinos, H.A. (2004): Returns to investment in education: a further update, in: Education Economics, Vol. 12, No. 2, pp. 111-134.

Rodrik, D., Subramanian, A., Trebbi, F. (2004): Institutions Rule: The Primacy of Institutions Over Geography and Integration in Economic Development, in: Journal of Economic Growth, Vol. 9, No. 2, pp. 131-165.

SAlA-I-MARTIN, X.X. (1997a): I just run 4 million regressions, in: NBER Working Paper, No. 6252 .

SAla-I-Martin, X.X. (1997b): I just ran 2 million regressions, in: The American Economic Review: Papers and Proceedings, Vol. 87, pp. 178-183.

Sanstad, A.H., Roy, J., Sathaye, J. A., (2006): Estimating energy-augmenting technological change in developing country industries, in: Energy Economics, Vol. 28, pp. 720-729.

Su, B., ANG, B.W. (2012): Structural decomposition analysis applied to energy and emissions: Some methodological developments, in: Energy Economics, Vol. 34, pp. 177-188.

SuE WING, I. (2008): Explaining the declining energy intensity of the U.S., in: Resource and Energy Economics, Vol. 30, pp. 21-49.

Syverson, C. (2011): What Determines Productivity?, in: Journal of Economic Literature, Vol. 49, No. 2, pp. 326-365.

Voigt, S., De Cian, E., Schymura, M., Verdolini, E. (2014): Energy Intensity Developments in 40 Major Economies: Structural Change or Technology Improvement?, in: Energy Economics, Vol. 41, pp. 47-62.

Wolfram, C., Shelef, O., Gertler, P. (2012): How Will Energy Demand Develop in the Developing World?, in: Journal of Economic Perspectives, Vol. 26, No. 1, pp. 119-138.

Wooldridge, J.M. (2002): Econometric Analysis of Cross Section and Panel Data, MIT Press, Cambridge, USA.

Wu, Y. (2012): Energy intensity and its determinants in China's regional economies, in: Energy Policy, Vol. 41, pp. 703-711.

ZHANG, Z., (2003): Why did the energy intensity fall in China's industry sector in the 1990s? The relative importance of structural change and intensity change, in: Energy Economics, Vol. 25 , pp. $625-638$.

Zhang, H., QI, Y. (2011): A Structure Decomposition Analysis of China's Production-Source CO2 Emission: 1992-2002, in: Environmental and Resource Economics, Vol. 49, pp. 65-77. 


\section{A Countries and Sectors in the WIOD-Database}

\begin{tabular}{lllc}
\hline \hline Countrycode & Country & Countrycode & Country \\
\hline AUS & Australia & JPN & Japan \\
AUT & Austria & KOR & Korea \\
BEL & Belgium & LVA & Latvia \\
BRA & Brazil & LTU & Lithuania \\
BGR & Bulgaria & LUX & Luxembourg \\
CAN & Canada & MLT & Malta \\
CHN & China & MEX & Mexico \\
CYP & Cyprus & NLD & Netherlands \\
CZE & Czech Republic & POL & Poland \\
DNK & Denmark & PRT & Portugal \\
EST & Estonia & ROM & Rumia \\
FIN & Finland & RUS & Slovakia \\
FRA & France & SVK & Slovenia \\
GER & Germany & SVN & Spain \\
GRC & Greece & ESP & Sweden \\
HUN & Hungary & SWE & Taiwan \\
IND & Tndia & TWN & Turkey \\
IDN & Indonesia & TUR & GUR \\
IRL & Ireland & GBR & United Kingdom \\
ITA & Italy & USA & United States \\
\hline \hline
\end{tabular}

Table 3: Country coverage of the WIOD database

\begin{tabular}{|c|c|}
\hline WIOD industries & NACE \\
\hline 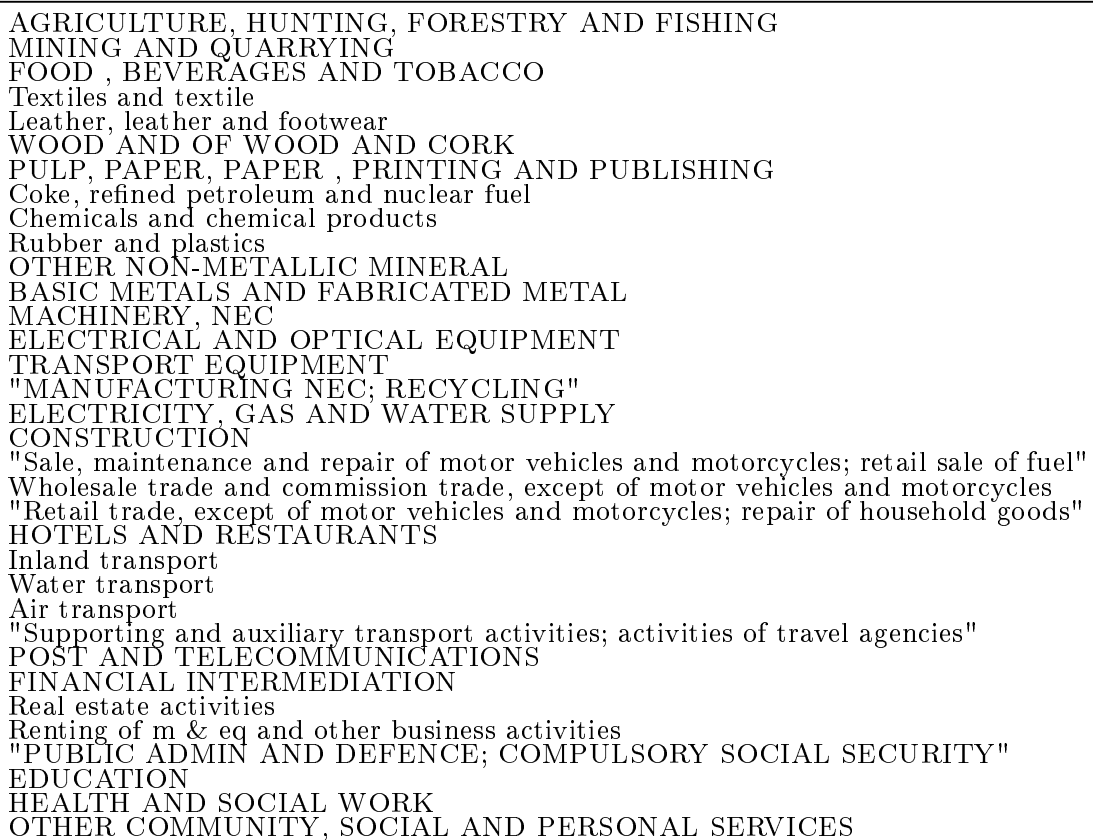 & $\begin{array}{r}\text { AtB } \\
\mathrm{C} \\
15 \mathrm{t} 16 \\
17 \mathrm{t} 18 \\
19 \\
20 \\
21 \mathrm{t} 22 \\
23 \\
24 \\
25 \\
26 \\
27 \mathrm{t} 28 \\
29 \\
30 \mathrm{t} 33 \\
34 \mathrm{t} 35 \\
36 \mathrm{t} 37 \\
\mathrm{E} \\
\mathrm{F} \\
50 \\
51 \\
52 \\
\mathrm{H} \\
60 \\
61 \\
62 \\
63 \\
64 \\
\mathrm{~J} \\
70 \\
71 \mathrm{t} 74 \\
\mathrm{~L} \\
\mathrm{M} \\
\mathrm{N} \\
\mathrm{O}\end{array}$ \\
\hline
\end{tabular}

Table 4: WIOD industries and definition by NACE 


\section{B Descriptive Statistics}

\begin{tabular}{|c|c|c|c|c|}
\hline Variable & Mean & SD & Min & Max \\
\hline Instrumented Per Capita Income (logarithmic) & 2.975 & 0.455 & 1.781 & 3.592 \\
\hline Instrumented Per Capita Income Squared (logarithmic) & 9.054 & 2.554 & 3.172 & 12.906 \\
\hline Instrumented Trade Openness (logarithmic) & 4.32 & 0.254 & 3.708 & 4.964 \\
\hline Share of Manufacturing Sector in the Economy (logarithmic) & 3.766 & 0.219 & 3.256 & 4.459 \\
\hline Capital to Labor Ratio (logarithmic) & 4.492 & 0.914 & 2.581 & 5.798 \\
\hline Capital to Labor Ratio Squared (logarithmic) & 21.009 & 7.898 & 6.662 & 33.614 \\
\hline Estimated Total Factor Productivity (logarithmic) & -0.603 & 0.376 & -1.523 & 0.053 \\
\hline Capital Vintaging (logarithmic) & 2.008 & 0.29 & 0.76 & 2.686 \\
\hline Energy Price (logarithmic) & -2.832 & 0.381 & -4.006 & -1.893 \\
\hline Regulation Index (logarithmic) & 0.805 & 0.988 & -0.693 & 3.239 \\
\hline Area in $\mathrm{km} 2$ (logarithmic) & 11.354 & 1.523 & 5.756 & 13.212 \\
\hline Population Growth in \% & 0.207 & 0.666 & -1.433 & 2.64 \\
\hline Geographical Latitude & 48.971 & 7.541 & 35 & 64 \\
\hline Heating Degree Days (logarithmic) & 7.854 & 0.562 & 5.726 & 8.699 \\
\hline Fromer Socialist Country & 0.385 & 0.487 & 0 & 1 \\
\hline Share of Green Energy & 0.119 & 0.104 & 0 & 0.401 \\
\hline
\end{tabular}

Table 5: Descriptive Statistics of used Variables

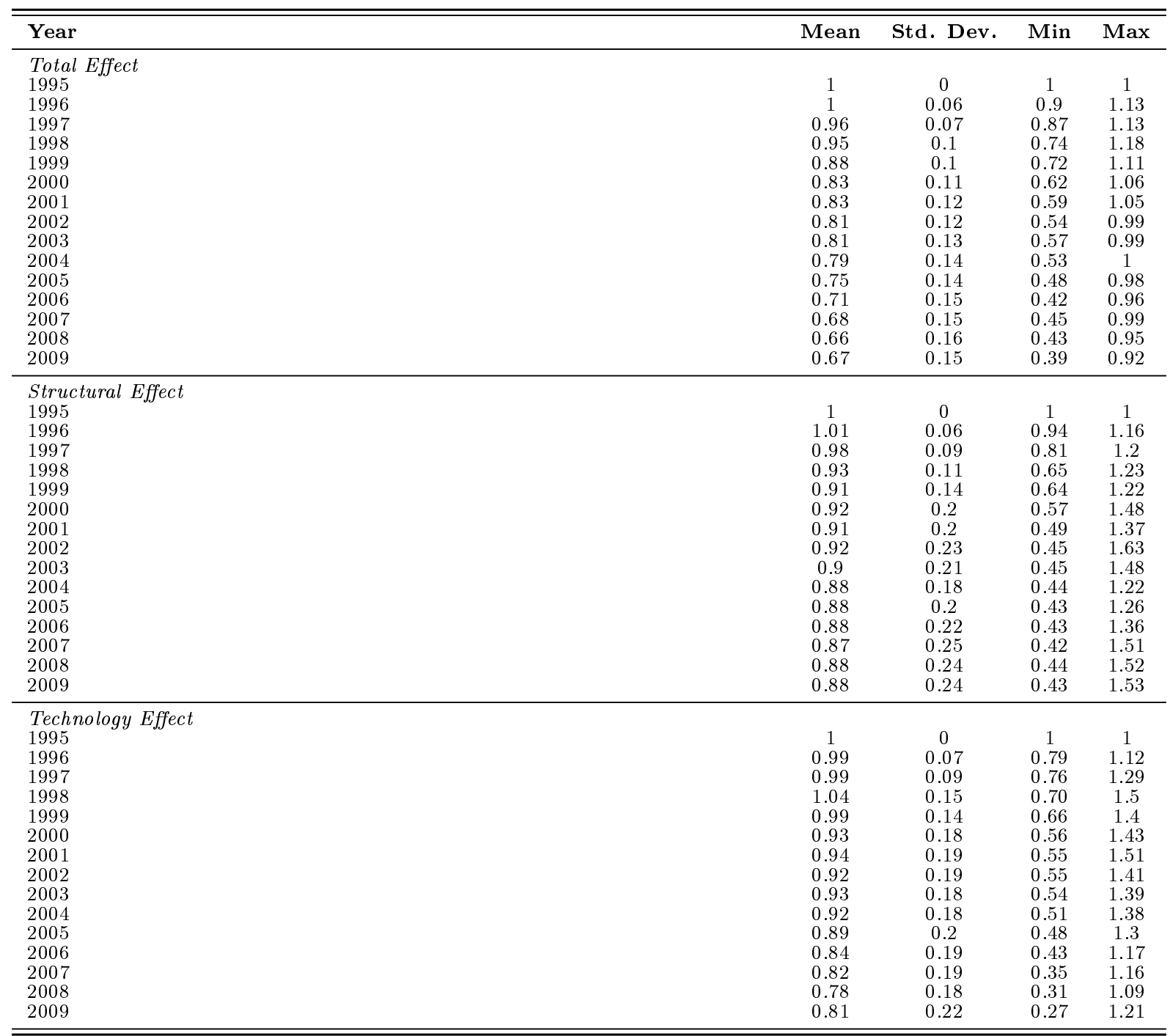

Table 6: Summary Statistics for the Country-Specific IDA (1995 = 1.00) 
C DEVELOPMENT OF EU27 ENERGY INTENSITY BETWEEN 1995 AND 2009 BY SECTOR

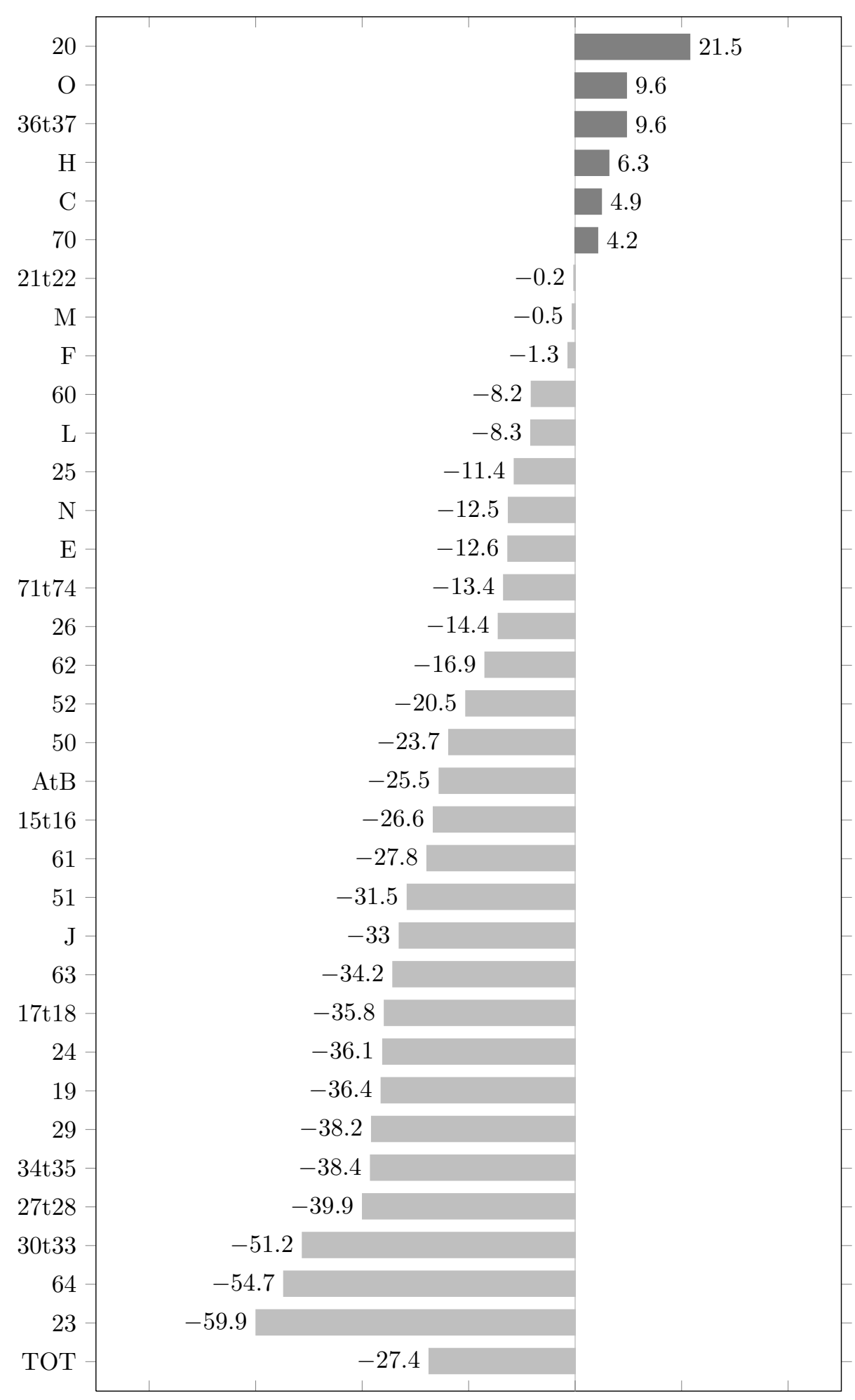

Figure 10: Sectoral Development of the EU27 Energy Intensity 


\section{The Trade Instrument}

We define real openness between country $j$ and country $k$ as:

$$
\text { Openess }_{j k t}=\frac{X_{j k t}+M_{j k t}}{G O_{j t} R E A L_{j, 1995}} ; \quad i \neq j
$$

The gravity equation estimated to obtain the geography-based bilateral trade share of two countries $j$ and $k$ is:

$$
\begin{aligned}
\ln \text { Openess }_{j k t}= & \gamma_{0}+\gamma_{1} \ln \text { Distance }_{j k t}+\gamma_{2} \ln \text { Pop }_{j t}+\gamma_{3} \ln \text { Pop }_{k t} \\
& +\gamma_{4} \ln \text { Area }_{j t}+\gamma_{5} \ln \text { Area }_{k t}+\gamma_{6}\left(L L_{j t}+L L_{k t}\right)+\gamma_{7} C B_{j k t} \\
& +\gamma_{8} C B_{j k t} \ln \text { Distance }_{j k t}+\gamma_{9} C B_{j k t} \ln \text { Pop }_{j t}+\gamma_{10} C B_{j k t} \ln \text { Pop }_{k t} \\
& +\gamma_{11} C B_{j k t} \ln \text { Area }_{j t}+\gamma_{12} C B_{j k t} \ln \text { Area }_{k t}+\gamma_{13} C B_{j k t}\left(L L_{j t}+L L_{k t}\right)+\varepsilon_{j k t}
\end{aligned}
$$

Our constructed trade share is then defined as:

$$
\text { Openess }_{j t}=\sum_{j \neq k} e^{\hat{\gamma^{\prime}} \boldsymbol{X}_{j k t}}
$$

The vector $\boldsymbol{\gamma}$ represents the coefficients in equation D20 whereas the vector $\boldsymbol{X}_{j k t}$ stands for the right-hand side variables in equation D20. From the first stage regression, fitted values where used to predict trade openness.

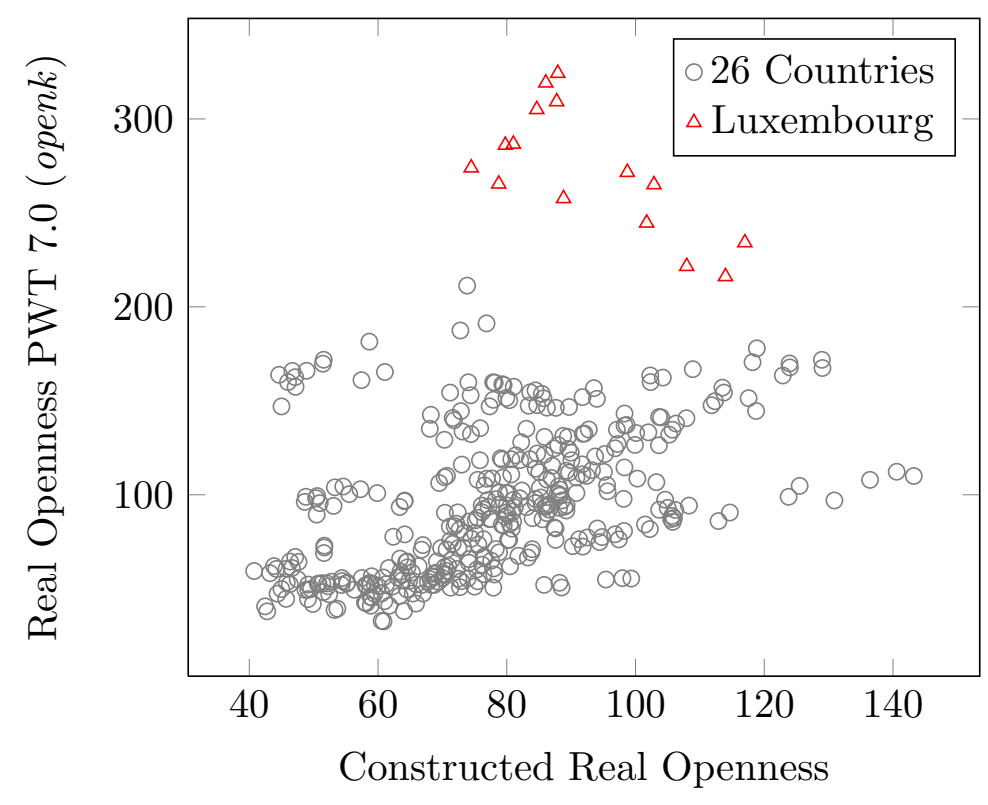

Figure 11: Constructed vs. Actual Trade Share 


\begin{tabular}{|c|c|c|}
\hline \multirow{2}{*}{$\begin{array}{l}\text { Dependent Variable: } \\
\text { Log OpenNess }\end{array}$} & \multicolumn{2}{|c|}{ OLS Estimates } \\
\hline & Coefficients & t-Statistic \\
\hline $\log _{-}$Distance & $\begin{array}{c}-0.943^{* * *} \\
(0.016)\end{array}$ & -58.10 \\
\hline $\log _{-} \mathrm{Pop}_{-} \mathrm{j}$ & $\begin{array}{c}-0.069^{* * *} \\
(0.013)\end{array}$ & -5.30 \\
\hline log_Area_j & $\begin{array}{c}0.043^{* * *} \\
(0.011)\end{array}$ & 0.04 \\
\hline $\log _{-} \mathrm{Pop}_{-} \mathrm{k}$ & $\begin{array}{c}0.531^{* * *} \\
(0.013)\end{array}$ & 40.25 \\
\hline $\log _{-}$Area_k & $\begin{array}{l}-0.003 \\
(0.010)\end{array}$ & -0.34 \\
\hline CommonLandlocked & $\begin{array}{c}-0.158^{* * *} \\
(0.028)\end{array}$ & -5.69 \\
\hline CB & $\begin{array}{c}0.573 \\
(0.403)\end{array}$ & 1.42 \\
\hline CB_ Dist & $\begin{array}{c}-0.359 * * * \\
(0.117)\end{array}$ & -3.06 \\
\hline $\mathrm{CB}_{-} \mathrm{Pop}_{-} \mathrm{j}$ & $\begin{array}{c}-0.472^{* * *} \\
(0.053)\end{array}$ & -8.94 \\
\hline CB_Area_j & $\begin{array}{c}0.612^{* * *} \\
(0.053)\end{array}$ & 11.49 \\
\hline $\mathrm{CB}_{-} \mathrm{Pop}_{-} \mathrm{k}$ & $\begin{array}{c}0.194^{* * *} \\
(0.047)\end{array}$ & 4.14 \\
\hline CB_Area_k & $\begin{array}{c}-0.223^{* * *} \\
(0.050)\end{array}$ & -4.45 \\
\hline $\mathrm{CB}_{-} \mathrm{LL}$ & $\begin{array}{c}0.273^{* * *} \\
(0.067)\end{array}$ & 4.6 \\
\hline constant & $\begin{array}{c}-2.196^{* * *} \\
(0.132)\end{array}$ & -16.654 \\
\hline
\end{tabular}

Model Summary:

$\begin{array}{lr}\text { Observations } & 22224 \\ \text { F-Statistic } & 839.59 \\ \text { Adj. } R^{2} & 0.266 \\ \text { Root-MSE } & 1.973\end{array}$

${ }^{*} \mathrm{p}<0.10,{ }^{* *} \mathrm{p}<0.05,{ }^{* * *} \mathrm{p}<0.01$, robust standard errors appear in parentheses

Table 7: Estimation Results for Gravity Model 


\section{E THE INCOME Instrument}

The estimation equation for the instrument of income is:

$$
\begin{aligned}
\ln \left(\frac{\text { Real_GDP }}{\text { Pop }}\right)_{j t}= & \alpha_{0}+\alpha_{1} \ln \left(\frac{\text { Real_GDP }}{\text { Pop }}\right)_{j t-1}+\alpha_{2} \ln \left(\frac{\text { Real_I }}{G D P}\right)_{j t} \\
& +\alpha_{3} \ln (n+g+\delta)_{j t}+\alpha_{4} \ln L A B H S_{j t}+\alpha_{4} \ln K_{j t}^{H_{c}} \\
& +\alpha_{4} \ln \left(\frac{K}{L}\right)+\alpha_{4} \ln \text { RealOpenness } s_{j t}+\varepsilon_{j t}
\end{aligned}
$$

\begin{tabular}{|c|c|c|}
\hline Dependent Variable: & Fixed Efi & Estimates \\
\hline log Real GDP per Capita & Coefficients & t-Statistic \\
\hline $\ln \left(\frac{\text { Real_GDP }}{\overline{P o p}}\right)_{j t-1}$ & $\begin{array}{c}0.881^{* * *} \\
(0.02)\end{array}$ & 45.67 \\
\hline $\ln \left(\frac{\operatorname{Real}}{G D \bar{P}} \frac{I}{j t}\right)_{j t}$ & $0.140^{* * *}$ & 7.15 \\
\hline $\ln (n+g+\delta)_{j t}$ & $\begin{array}{c}(0.02) \\
-0.137^{* * *} \\
(0.03)\end{array}$ & -4.57 \\
\hline $\ln L A B H S_{j t}$ & $\begin{array}{c}0.030^{*} \\
(0.02)\end{array}$ & 1.96 \\
\hline $\ln K_{j t}^{H_{c}}$ & $\begin{array}{l}0.186 \\
(0.11)\end{array}$ & 1.68 \\
\hline $\ln \left(\frac{K}{L}\right)$ & -0.018 & -0.63 \\
\hline $\begin{array}{l}\text { In RealOpenness } j t \\
\text { constant }\end{array}$ & $\begin{array}{l}(0.03) \\
0.011 \\
(0.03) \\
0.323^{*} \\
(0.18)\end{array}$ & 0.42 \\
\hline $\begin{array}{l}\text { Model Summary: } \\
\text { Observations } \\
\text { F-Statistic } \\
\text { Adj. } R^{2}\end{array}$ & $\begin{array}{c}375 \\
1332.95 \\
0.9797\end{array}$ & \\
\hline
\end{tabular}

Table 8: Estimation Results for Income Instrument

\section{F Comparison OF OUR RESUlts TO METCALF (2008)}

In this section we compare our results to the ones in Metcalf (2008). We reported fixed-effects panel estimations using the obtained index values as the dependent variables. 


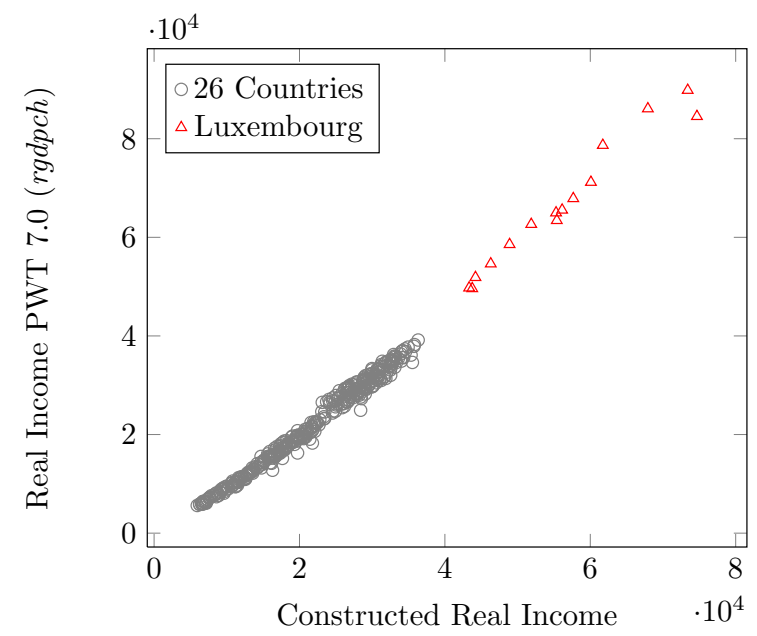

Figure 12: Constructed vs. Actual Real Income per Capita

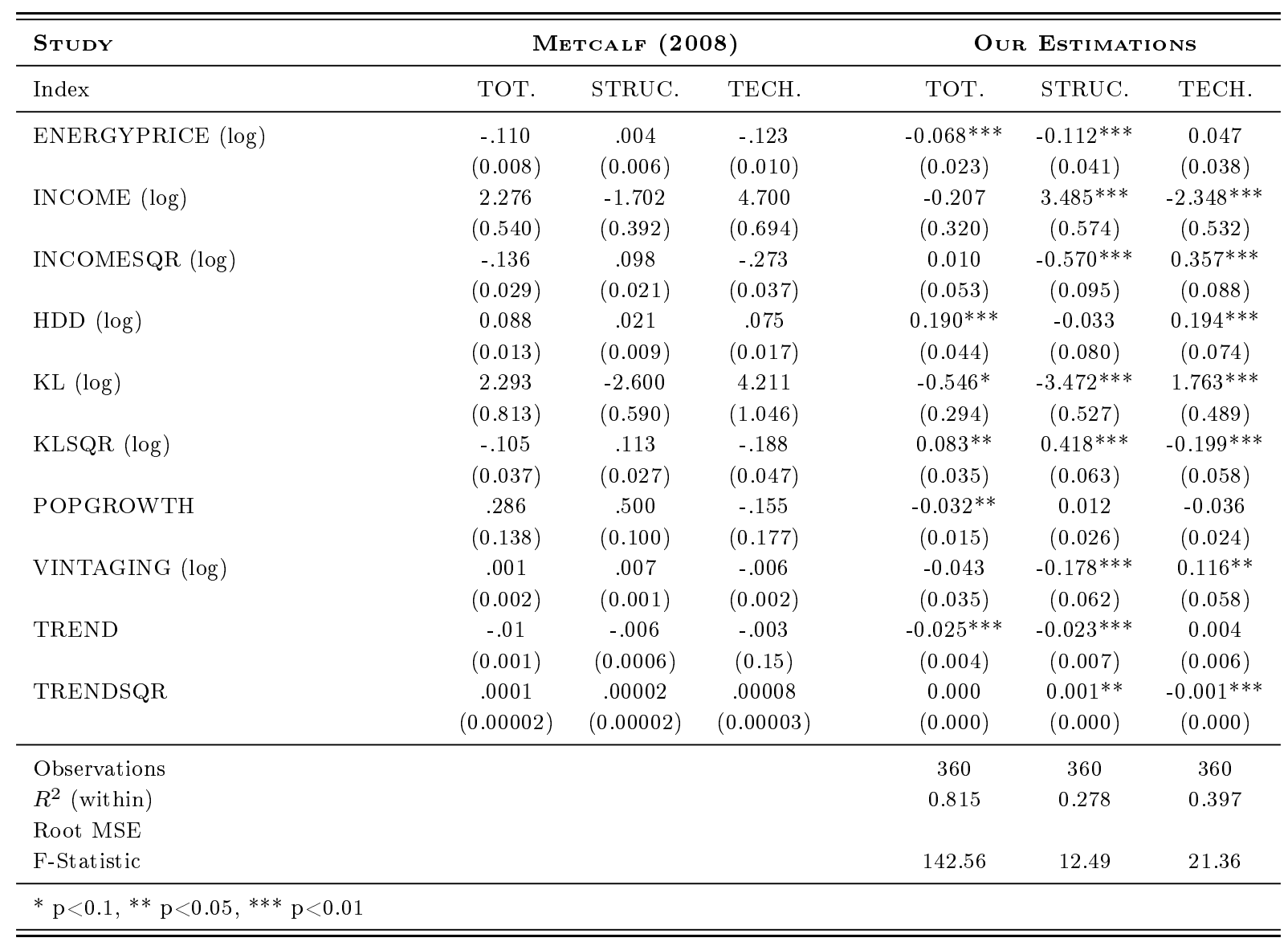

Table 9: Our results compared to Metcalf 2008)

Table 9 presents the results for the comparison with the study by Metcalf (2008) on U.S. energy intensity by state between 1970 and 2001. Our coefficient for energy prices indicates that a $10 \%$ increase in energy prices results in a decline of energy intensity of $0.68 \%$. The effect is even stronger for the index value of the structural effect $(-1.1 \%)$. In both models the effect is 
statistically significant $(p<0.01)$. Surprisingly, the index value for the technology effect is not affected by the energy price. In contrast to Metcalf (2008), income (and its squared term) has no impact on the total effect. This is mainly due to the shorter time-period under investigation. Yet when we hold technology constant, the effect of INCOME and INCOMESQR supports an increasing, but inverted, u-shape relation between income and energy intensity. The calculated turning point - when an increase in INCOME leads to an increase in energy intensity - is $\approx$ 21,200 US-\$ (1995). This is exactly the median of the INCOME in our sample. In other words, an increase in income leads to a decrease in energy intensity in half of the sample, provided technology holds constant. Countries with more heating degree days have, ceteris paribus, a higher index value for energy intensity. The magnitude is larger than in Metcalf's study. The most significant differences in our estimates are the coefficients for the capital-to-labor ratios. An increase in the capital-to-labor ratio leads to a decrease in the total effect and in the structural effect. The turning point for the total effect is a capital-to-labor ratio of 26.3 , or around the $15 \%$ percentile in the distribution of the sample's capital-to-labor ratios. The corresponding turning point for the structural effect - again, holding technology constant - is 63.8 (around the $30 \%$ percentile). The estimate for POPGROWTH is negative and significant on the $5 \%$-level for the total effect index. Hence, fast growing countries have lower energy intensities. The capital vintaging effect is only observable in the regressions of the structural index. There, countries with higher investment-to-gross-output ratios tend to have lower energy intensity. The time trend variables are negative and significant in the models that explain the total effect and the structural effect. 